\title{
The Golden Horde, the Spanish Habsburg Monarchy, and the Construction of Ruling Dynasties
}

\author{
Marie Favereau Doumenjou and Liesbeth Geevers
}

Introduction: What is Dynastic Rule?

When reading historical works one gets the impression that 'dynasty' is an obvious and ubiquitous notion. ${ }^{1}$ Historians make use of the term to identify ruling lineages (the Jagiellonians, the Shibanids) and to structure time (Tudor England, Safavid Iran, Ming China). However, even in a Western context, the term dynasty was rarely used before the sixteenth century, and many of our dynastic labels were unknown to the people who are now identified by them. ${ }^{2}$ In a sense, historical dynasties are thus in part the historian's invention.

Yet, dynastic rule, understood as a political regime, remains a key tool to study empires. Even if they were all intrinsically different, empires had in common the fact that they were not nation states, nor republics, but they were usually headed by hereditary rulers (or conquerors who wanted to establish hereditary rule). What is more, the fate of the dynasty was closely connected to the fate of the empire. A lack or an abundance of heirs might lead to the collapse of the empire and the dispersion of its territories. These factors caused dynasties to be perhaps the main agent of cohesion within empires, so the question how dynasties maintained their position of power-by passing on their territories to their heirs, by constructing a loyalty-inspiring idea of their identity and mission, and by functioning as a ruling group — should be a central one in the study of empires. Dynastic rule was deeply intermingled with

1 As Jeroen Duindam's recent study pointed out, dynasty is almost a universal and yet an ongoing process that needs to be contextualized and conceptualized: Duindam, Dynasties: A Global History of Power, 1300-1800 (Cambridge, 2015).

2 The Jagiellonians, for example, never referred to themselves as such before the sixteenth century. See 'The Jagiellonians', a E RC-funded project led by Natalia Nowakowska. Consulted online on 23 November 2016: http://www.jagiellonians.com/. 
kinship in most Eurasian empires. ${ }^{3}$ Emperors, shahs, khans, and kings, whatever title(s) they used, often inherited their position because of their familial affiliations (including kinship through marriage or adoption). But even in elective systems, in which family connections supposedly were less important, the rulers had to be part, to some extent, of the ruling lineage. ${ }^{4}$

One more point needs to be stressed: the hereditary or elective ruler did not always rule as a monarch, that is, on his own. Collective forms of government were, in fact, standard. As Jeroen Duindam has pointed out, many discrepancies could exist between the ideal of a virile, warrior ruler and reality-which might see weak or underage individuals on the throne, who were much more dependent on their entourage. ${ }^{5}$ Also, Theresa Earenfight has argued recently that 'kingship' is too often narrowly defined as the rule of one (usually male) individual, while in practice rulers were always aided by others in their immediate vicinity - their spouses, advisers, generals, or relatives. She suggests using the term 'rulership', conceptualized as a 'flexible sack' that allows space for the ruler and any of his immediate 'co-workers' who were his partners in rule. ${ }^{6}$ Clearly, whenever the actual ruler did not fit the model of the strong leader, or in fact, in any situation, we must take into account others who were indispensable for the rule of the empire.

Since succession was at times elective, and dynastic rule was more collegial than is commonly assumed - basically it was an oligarchic regime-we should think of dynasties as groups rather than as sequences of individual rulers. Accepting this as our point of departure, we choose to analyse in depth the construction of such 'dynastic groups' at the centre of the Golden Horde and the Spanish Habsburg Monarchy, adopting a more concentrated comparative approach than our colleagues. Rather than placing our dynasties in the context of the court (which has been discussed at length in chapter 1) we will focus on the dynastic groups themselves and trace their evolution and internal structure.

3 This was a widespread phenomenon, but not universal (the Mamluks and the Holy Roman Empire are cases in point).

4 Armin Wolf, 'The Family of Dynasties in Medieval Europe: Dynasties, Kingdoms and Tochterstämme', Studies in Medieval and Renaissance History 12 (1991) 183-26o argues that although the Holy Roman imperial title was elective, the chosen one was usually a close relative of his predecessor at least in the female line.

5 Duindam, Dynasties, chapter 1.

6 Theresa Earenfight, 'Without the Persona of the Prince: Kings, Queens and the Idea of Monarchy in Late Medieval Europe', Gender \& History 19, no. 1 (2007) 1-21. 
How will we do this? Historians have not pondered the concept of dynasty or dynastic groups at length, but the few definitions that are available provide useful building blocks for our approach. Wolfgang Weber, writing about early modern Europe, points out that the formation of a dynasty entailed more than simply mechanisms to safeguard family assets for future generations. Cultural issues were also involved, for instance the 'historicizing' of kinship ties by replacing the unclear and recent family roots with the 'discovery'that is to say, in many cases the creation - of a more extended line of descent. The purpose of the dynasty was not only to transmit the family's material and immaterial assets, but also to embody the sense of obligation to keep on doing this. ${ }^{7}$ In this way, being part of a dynasty meant a lack of freedom to act in one's own best interest and an obligation to act in the best interest of the wider collective. To impose such discipline, successful dynasties depended on socializing the offspring into the dynasty. ${ }^{8}$

Comparable concepts from the steppe world exist. The Mongols called the lineage of Chinggis Khan the 'golden lineage', which we shall discuss at length in this chapter. Sergei Nekluidov emphasizes the meaning of the 'gold' quality of the Chinggisid lineage, by stating:

At its base lay first of all, two mythological ideas: eternity (indestructibility, agelessness) and value (initiating principle, essence), which form four semantic categories (or fields): the golden source, golden principles, golden center, and golden essence (the very highest degree of quality). ${ }^{9}$

7 Wolfgang E.J. Weber, 'Dynastiesicherung und Staatsbildung. Die Entfaltung des frühmodernen Fürstenstaates', in: Wolfgang E.J. Weber, ed., Der Fürst. Ideen und Wirklichkeiten in der europäischen Geschichte (Cologne, 1998) 91-136, 95: 'eine optimierte Erscheinungsform der Familie, die sich durch erhöhte Identität (und damit verstärkte Abgrenzung nach Außen), ausdrücklich gemeinsam genutzten (individueller Verfügung durch Familienmitglieder entzogenen) Besitz (Güter, Ränge, Rechte, Ämter), im Interesse ungeschmälerter Besitzweitergabe bzw. maximaler Besitzerweiterung bewußt gesteuerte Heirat und Vererbung sowie daher in der Regel gesteigerte historische Kontinuität auszeichnet. Sowohl die Entstehung einer Dynastie als auch deren Verfestigung sind deshalb wesentlich als Ergebnis bewußten Handelns aufzufassen, welchem entsprechend typische Elemente und Muster zugeschrieben werden können.'

8 Weber, 'Dynastiesicherung', 98-99.

9 Sergei Iu. Nekliudov, 'Zametki o mifologicheskoi i fol'klorno-epicheskoi simvolike y mongol'shikh narodov: simvolike zolota', Etnografia Polska 24, no. 1 (1980) 65-94, 86. Quoted in Thomas T. Allsen, Commodity and Exchange in the Mongol Empire: A Cultural History of Islamic Textiles (Cambridge, 1987) 61. 
When we apply these ideas to the Chinggisid lineage, we have an image of an indestructible and ageless lineage whose members possessed the very highest degree of quality. More recently, Tatyana Skrynnikova has shown how Chinggis Khan successfully established the supremacy of his own lineage over all others, including the old ruling lineages of the Kereit and the Naiman. ${ }^{10}$

Chinggis Khan was not only successful on the battlefield; he was a seasoned politician. He created a new hierarchy among the steppe peoples in which prestige was associated with his person, ancestors, next of kin, and close friends. After his death in 1227, the Chinggisid patrilineality remained the backbone of the Mongol imperial power, but the succession process passed into the hands of the Mongol elites. The Chinggisid extended family and the non-Chinggisid groups that belonged to the maternal lines of the throne contenders took part in the succession process. Thus the choice of the new khan was always the result of elite consensus, and the Chinggisid dynasty, with its golden lineage, was the end product of complex political negotiations.

Both European and Asian examples point to the existence of a collective identity among members of dynasties, since they display a shared awareness of belonging to a group and their actions were shaped by this awareness. We will therefore approach dynastic groups as collectives, focusing on the construction of their identities and the workings of their internal relationships. To this general approach, we need to add an analysis of succession practices. After all, the defining element of any dynasty is that there was something-lordships or other positions of power, status, moveable assets, and claims to them, but also, in our own times, companies, etc.- to be passed on to the next generation.

10 Tatyana Skrynnikova, 'Relations of Domination and Submission: Political Practice in the Mongol Empire of Chinggis Khan', in: David Sneath, ed., Imperial Statecraft: Political Forms and Techniques of Governance in Inner Asia, Sixth-Twentieth Centuries (Bellingham, wA., 2007) Chapter 3, 85-115. On the socio-political organizations of the east-Asian steppe world in the twelfth and thirteenth centuries and the formation of the Mongol empire, see Christopher Atwood, 'Borjigid' and 'Mongol Tribe', in: Christopher Atwood, Encyclopedia of Mongolia and the Mongol Empire (New York, 2004) 44-45;389-391; Christopher Atwood, 'How the Mongols Got a Word for Tribe-and What It Means', Studia Historica Mongolica 10 (2010) 63-89; Isenbike Togan, Flexibility \& Limitation in Steppe Formations. The Kerait Khanate \& Chinggis Khan (Leiden, 1998); Lhamsuren Munkh-Erdene, 'Where Did the Mongol Empire Come From? Medieval Mongol Ideas of People, State and Empire', Inner Asia 13 (2011) 211-237; Paul Buell and Judith Kolbas, 'The Ethos of State and Society in the Early Mongol Empire: Chinggis Khan to Güyük', Journal of the Royal Asiatic Society 26 (2016) $43-56$. 
The process of distributing such assets is closely connected both to the identity of the group (relating to a certain area, or to a certain mythical ancestor) and its internal dynamics (defining the hierarchy among the main inheritors, minor inheritors and those who lost out altogether). ${ }^{11}$ Focusing on the evolving practices surrounding the succession, the construction of identities, and social relations among family members will bring us closer to understanding how dynastic ruling groups shaped and maintained their empires.

In this chapter, we look at these three key components of the dynasty: the generational transfer of dynastic assets, its conceptual underpinning, and the social reality of rule in two historical contexts. We will deal first with the Golden Horde, and then we turn to the Spanish Habsburg Monarchy. The two parts of this chapter share the same tripartite layout. In the first section we discuss how the lineage developed its succession practices through written and oral laws and non-codified traditions, and we discuss the conditions of access to the throne. Such practices were invariably developed through negotiations with powerful leaders and elites. In the second section we unravel the dynastic concept to show a) how the lineage connected itself to its possessions, justifying its position at the apex of society; b) how individuals claimed membership in the lineage and thus access to its assets, and/or c) how members of the lineage conceived of themselves as a group, being 'glued' together by common descent, common traditions, and common characteristics. ${ }^{12}$ The third section will concern the social reality of dynastic rule. As we have noted above, dynastic rule was often more collegial or oligarchic than historians have presented, so we will analyse the roles different members of the dynastic family played in ruling the empire and how this social reality relates to the concepts that were developed.

Why did we choose the Jochids, Chinggisid rulers of the Golden Horde, and the House of Austria, whose Spanish branch ruled the Spanish Habsburg Monarchy as our case studies? They appear to represent extremely different cases that are often accepted as models for contrasting European and Asian imperial traditions. Both fit in a wider dynastic tradition: respectively

11 O.J. Hekster, Emperors and Ancestors: Roman Rulers and the Constraints of Tradition (Oxford, 2015) follows a similar approach in his seminal work, discussing in his Introduction first succession, family structure, and representation (as well as notions of kingship) to define dynastic rule.

12 Lynette Mitchell and Charles Melville, "'Every Inch a King." Kings and Kingship in the Ancient and Medieval Worlds', in: Lynette Mitchell and Charles Melville, eds., Every Inch a King: Comparative Studies on Kings and Kingship in the Ancient and Medieval Worlds (Leiden and Boston, 2013) 1-23, 3. 
the Chinggisids and the longer-lasting Austrian Habsburgs. The Habsburgs are frequently depicted as the typical, stable European dynasty, ruling its various domains for many centuries and, on the whole, following a steady pattern of succession. The Chinggisids, conversely, are seen as the epitome of the dynamic and violent steppe tradition, with ever-contested successions known mostly for their meteoric rise to power and limited capacity for consolidation. Spanish Habsburgs ruled over European populations organized into different political entities (like the kingdom of Castile and the duchy of Milan), for the most part Christian and sedentary; the Golden Horde stretched over Russia and Central Asia and was predominantly Muslim and controlled by nomads. However, both in the Golden Horde and the Spanish-Habsburg composite state, the royal lineage was a key institution, which held people together in the absence of other institutions that could perform this function (such as the Parliament in England). Both, as we have seen, were connected to a meta-empire, the medieval Habsburgs and the Chinggisids respectively, but established their rule in new areas; in fact they were almost equally successful and enduring, ruling from 1504 to 1700 and the 1220 s to the 155 os respectively. Within their own geographical and chronological contexts, the Chinggisids and their offshoots were among the most influential Asian dynasts, whose 'governing practices' and legitimizing charisma would dominate later Central Asian and Crimean khanates, while the Habsburgs count among the most successful dynasties in Europe, presiding over an impressive conglomerate of states, of the type that is nowadays held as typical for early modern Europe. These two cases will allow us to make an in-depth comparison of dynastic rule, based on our knowledge of relevant primary sources for each case. By working together, each of us building on and expanding her previous regional expertise, we intend to avoid a lopsided comparison which favours one case over the other and thus reinforces clichés. We take neither of the two cases as the model with which the other is contrasted, but rather wish to approach each case on the basis of the open questions and criteria we have sketched above. This empirical and open-minded approach should allow us to gain insights into the phenomenon of dynastic rule, which may be applicable more generally — to other periods and other empires.

The aim of our comparative research is not to give a list of differences and similarities, but to re-think our use of the terms 'dynasty' and 'dynastic rule' in general. How should historians break down these terms in order to make sense of the political structure at the centre of empires? We aim to show that 'dynasty' had various meanings - the often haphazard sequence of rulers that were related to each other; the stories they developed to justify their rule, that could change as the circumstances of rule changed; but also the 
'mixed bag' of others who were essential for rule but were not necessarily part of the dynastic discourse. In expanding our understanding of what 'dynasty' is, we intend to undermine detrimental clichés about European and Asian historical developments that stand in the way of source-based comparisons, and thus we aim to provide a research agenda for future global historians of empires.

\section{The Golden Horde}

1.1

\section{How to Become Khan}

1.1.1 The Mongol Empire's Achilles Heel

The formation of the Mongol empire was a revolution that turned the Old World upside down. Under the banner of Chinggis Khan (c. 1165-1227), the nomads of the Eurasian steppes unified and expanded on an unprecedented scale. From their core area, the Onon valley in northern Mongolia, they conquered and integrated China, Central Asia, Anatolia, Eastern Europe, Russia and the Siberian plains, Afghanistan, and Iran. At its height, in 1279, the Great Mongol Empire embraced the two thirds of Eurasia.

The Yeke Mongghol Ulus, Great Mongol Empire, was the largest nomadic empire of Eurasia as the Mongols reached the ecological limits of the continental steppes. Its formation occurred in the vein of a successful series of political regimes that flourished in the Eurasian steppes over a millennium. The Mongols were aware of this historical continuity and claimed the legacy of the former polities that had created huge superstructures, especially the Türk (c. 552-743), the Uyghurs (744-840), and the Khitan (907-1125). They captured their political prestige, copied their administration, and claimed the same agenda: unifying 'the people of the felt-walled tents', the nomads of the steppes. ${ }^{13}$ They built their imperial city of Qara Qorum in the sacred land of the Türk, the Orkhon Valley, and chose the Uyghur script as their imperial script. They also consciously created a new regime. The Secret History of the Mongols,

13 On the legacies of the previous steppe empires and the rich repertoire of political symbols and practices that were available to the Mongols, see Nicola Di Cosmo, 'Ancient Inner Asian Nomads: Their Economic Basis and Its Significance in Chinese History', Journal of Asian Studies 53 (1994) 1092-1126; 'State Formation and Periodization in Inner Asian History', Journal of World History 10 (1999) 1-40; Ancient China and its Enemies: the Rise of Nomadic Power in East Asian History (Cambridge, 2002). On the critical notion of repertoire of power, see Jane Burbank and Frederick Cooper, Empires in World History: Power and Politics of Difference (Princeton, 2010). 
like all the official histories of the Mongols, emphasize Chinggis Khan's role of founder. His title of 'universal ruler' captured his intention to be a groundbreaking ruler, more powerful than his predecessors. ${ }^{14}$

In accordance and agreement with his own mind he [Chinggis Khan] established a rule for every occasion and a regulation for every circumstance; while for every crime he fixed a penalty. And since the Tartar peoples had no script of their own, he gave orders that Mongol children should learn writing from the Uighur; and that these yasas and ordinances should be written down on rolls. These rolls are called the Great Book of Yasas and are kept in the treasury of the chief princes. Wherever a khan ascends the throne, or a great army is mobilized, or the princes assemble and begin [to consult together] concerning affairs of state and the administration thereof, they produce these rolls and model their actions thereon. ${ }^{15}$

From eastern to western Asia, the Mongol empire swallowed the biggest empires of their time: the Tangut, the Jin, the Song, the Qara-khitan, the Khwarazmshah, the Abbasids, and the Seljuks of Rum. As 'the only super-power' of the thirteenth century, the Mongols dictated a new world order and created alternative nexuses of exchanges. Under their rule, the leading political centres of the continent were moved closer to the steppes hinterland: Kaifeng, Hangzhou, Balasaghun, Kiev, and Baghdad were replaced by Qara Qorum, Almaliq, Beijing, Saray on the lower Volga, Maragha, and Tabriz. ${ }^{16}$ The great khans became potential allies for the Latin world and received embassies from the kings of France, England, the Holy Roman Empire, and the Papacy. After two centuries of clashes between Christians and Muslims, the Mongols appeared as the third force that might break the status quo and tilt the balance in favour of Christendom. In fact, the attitude of the Mongols towards religion was very different from European and Islamic practices as they accumulated

14 On the possible meaning of this title, see Igor de Rachewiltz, 'The Title Činggis Qan/Qayan Reconsidered', in: Walther Heissig and Klaus Sagaster, eds., Gedanke und Wirkung. Festschrift zum 9o. Geburstag von Nikolaus Poppe (Wiesbaden, 1989) 281-298.

15 'Ala-ad-Din 'Ata-Malik Juvayni, Genghis Khan: The History of the World Conqueror, trans. J.A. Boyle (Manchester, 1958) vol. 1, 25. Juvayni was a Persian secretary working for the Mongols, who wrote this text in the early 1250 s.

16 Michal Biran, 'The Mongol Empire and Inter-Civilizational Exchange', in: Benjamin Z. Kedar and Merry E. Wiesner-Hanks, eds., The Cambridge World History. Volume 5: Expanding Webs of Exchange and Conflict, 5OOCE-150OCE (Cambridge, 2015) 534; 554. 
religious beliefs rather than focusing on one single confession. Even after some Mongol rulers converted to Christianity and others to Islam and Buddhism, they never forced their subjects to follow their choice. ${ }^{17}$

After Chinggis Khan died in August 1227, it took the Mongols two years to agree on his successor: Ögödei (r. 1229-1241). The right to rule was held exclusively by Chinggis Khan's family, but the final decision remained in the hands of a much larger group. Instead of following the steppe herders' inheritance laws, which might have inspired Chinggis Khan when he apportioned his subject peoples and their lands among his next of kin, the supreme office was not passed on to Tolui, his youngest son. ${ }^{18}$ The official version has opportunely established that, a few years before he died, Chinggis Khan designated his third son Ögödei as his heir. But he was not Chinggis Khan's first choice.

Jochi, the eldest son of Chinggis Khan and his chief wife Börte, was the heir apparent until the Central-Asian campaign of 1219-1221. ${ }^{19}$ Indeed Chinggis Khan gave him not only the biggest lot of peoples and territories, he granted him a leading position in the western and north-western campaigns:

When during the reign of Chingiz-Khan the kingdom became of vast extent he assigned to everyone his place of abode, which they call yurt ... To his eldest son, Tushi [Jochi], he gave the territory stretching from the regions of Qayaligh and Khorazm to the remotest part of Saqsin and Bulghar and as far in that direction as the hoof of Tartar horse had penetrated. ${ }^{20}$

17 On the Mongol religious tolerance (as a distinctive political tool) see: Christopher Atwood, 'Validation by Holiness or Sovereignty: Religious Toleration as Political Theology in the Mongol World Empire of the Thirteenth Century', The International History Review 26, no. 2 (2004) 237-256; Peter Jackson, 'The Mongols and the Faith of the Others', in: Reuven Amitai and Michal Biran, eds., Mongols, Turks and Others (Leiden, 2005) 245-29o.

18 On pre-mortem inheritance laws and traditions in the East-Asian steppe and on how they might have inspired Chinggis Khan's apportionment system, see Jennifer Holmgren, 'Observations on Marriage and Inheritance Practices in Early Mongol and Yuan Society, With Particular Reference to the Levirate', Journal of Asian History 20, no. 2 (1986) 148149; Christopher Atwood, 'Family', in: Christopher Atwood, Encyclopedia of Mongolia and the Mongol Empire (New York, 2004) 173-174.

19 Christopher Atwood, 'Jochi and the Early Western Campaigns', in: Morris Rossabi, ed., How Mongolia Matters: War, Law, and Society (Leiden and Boston, 2017) 35-56.

$20 \quad$ Juvayni, The History of the World-Conqueror, 42. 
But Jochi died in February 1227, a few months before his father. ${ }^{21}$ His son Batu, who succeeded him, could not compete with his uncles to claim the throne of Chinggis Khan as he was a junior. ${ }^{22}$ After Jochi's death, his descendants - though they were able to keep a prominent place in the empirewere evicted from the imperial succession by the other branches of the Chinggisid family. The Ögödeids, who ruled until the death of Great Khan Güyük (r. 1246-1248), and the Toluids who managed to hold power from the reign of Great Khan Möngke onwards (r. 1251-1259), were the most successful lineages. In less than a generation, the descendants of Chagatay, like the descendants of Jochi, were displaced from the central power. But they still had some say in the succession process and could interfere with the choice of the candidates.

After the death of Möngke, two candidates competed for the throne: Kublai and Arigh Böke. The Jochids supported Arigh Böke and refused to recognize Kublai as the new great khan. The political disagreement turned into an interMongol war. In 1264, Kublai finally eliminated Arigh Böke but could not prevent the empire from splitting. The four ulus, sub-empires, that emerged were all headed by grandsons and great-grandsons of Chinggis Khan; yet, they sanctioned the domination of the lineages coming from only three of his sons: the Toluids (later known as the Yuan) ruled over China, Tibet, and Mongolia, as well as Iran, Azerbaijan, Iraq, and Eastern Anatolia (later known as the Ilkhanate); the Chagatayids ruled over parts of Central Asia (later known as the Chagatay Khanate); and the Jochids over western Kazakhstan, Southern Siberia, Russia, and Eastern Europe (later known as the Golden Horde). ${ }^{23}$ The Ögödeids were

21 Later sources stated that in reaction to Chinggis naming his third son Ögödei as his successor, Jochi rebelled against his father. His brothers Chagatai and Ögödei were ready to fight him. However, he died before the succession struggle took a military turn. On the strong anti-Jochid bias of the Toluid sources, see Atwood, 'Jochi and the Early Western Campaigns', $35^{-38}$.

22 On the crucial distinction between senior and junior statuses, called aga, elder brothers, and ini or otchigin, younger brothers, see Skrynnkova, 'Relations of Domination and Submission', 87 .

23 On the expression 'Golden Horde' and the Turko-Mongol use of the term horde (ordu, orda) see István Vásáry, 'The Jochid Realm, the Western Steppes, and Eastern Europe', in: Nicola Di Cosmo, Allen Frank, and Peter Golden, eds., The Cambridge History of Inner Asia: The Chinggisid Age, (Cambridge, 20o9) 68; and Takushi Kawaguchi and Hiroyuki Nagamine, 'Rethinking the Political System of the Jöchid', Acta Orientalia Academiae Scientiarum Hung. 69, no. 2 (2016) 165-181. The term horde itself can be traced back to the time of Early Han (207 B.C.-9A.D.): Karl Wittfogel and Fêng Chia-shêng, History of Chinese Society: Liao (907-1125) (Philadelphia, 1949) 19; 508-509 and section XV, 505-570. 
the biggest losers of the Mongol succession war of the 126os. In the new political arrangement they had no ulus of their own. ${ }^{24}$

After the collapse of the old empire began the long century of 'the Mongol commonwealth' centred on Pax Mongolica, a set of commercial agreements. The four sub-empires maintained the dynamics of expansion. They remained connected, but their exchanges did not prevent the growth of local strategies; several military conflicts saw the Yuan opposed to the Chagatayids while the Ilkhanate battled the Golden Horde. In 1304, imperial unity was reasserted and peace was declared between the four sub-empires. The Yuan kept the overarching title of 'great khan' and enjoyed a nominal primacy over the three other parts. In fact, the hierarchy among them was not pyramidal, even though their ulus were not equal in size. ${ }^{25}$

The Chagatayids had obviously the smallest lot. The Toluids ruled over the largest territories, but they were divided between the Ilkhanids and the Yuan; besides their lands were not contiguous, and the Toluids had to deal with the Chagatayids and the Jochids who controlled the buffer regions in Central Asia. The Jochids had not only the biggest contiguous area, but it was also an unclosed territory open on its western border to Eastern Europe and the Black Sea, the Mediterranean world, and northern Africa.

In 1335, the descendants of Hülegü lost the throne of the Ilkhanate and their dominions passed into non-Chinggisid hands. In 1368 the Mongol Yuan were defeated and the Ming took over China, but the Chagatayid Khanate and the Golden Horde remained powerful. The former, led by Timur (c. 13701405), developed into a new empire and was still a significant power in the seventeenth century, while the latter kept the upper hand on the north-western steppes, dominating Russia until 148 os. In the sixteenth century, the growing powers of the area, Muscovy and the Ottoman Empire, subdued the Jochids of the Ural-Volga and of the Dnieper basin.

24 The eviction of the Ögödeids started under Great Khan Möngke who purged the empire of his rivals. Peter Jackson, 'From ulus to khanate: The Making of the Mongol States, c. 1220129o', in: Reuven Amitai-Preiss and David O. Morgan, eds., The Mongol Empire and its Legacy (Leiden and Boston, 1999) 12-38; on the notion of dynasty applied to the Yuan, see Hodong Kim, 'Was ‘Da Yuan' a Chinese Dynasty?', Journal of Song-Yuan Studies 45 (2015) 279-305.

25 On the concept and phenomenon of Pax Mongolica, see Hodong Kim, 'The Unity of the Mongol Empire and Continental Exchanges over Eurasia', Journal of Central Eurasian Studies 1 (2009) 15-42; Timothy May, The Mongol Conquests in World History (London, 2012) 109-256. 
Several Chinggisid khanates survived nevertheless until the nineteenth century. The lineage of Chinggis Khan kept its prestige and continued to produce rulers - though they often ruled nominally. The Manchu Qing emperors (16441911) were still considered as incarnations of Chinggis Khan and his grandson Kublai; and in eighteenth-century Crimea, only a Jochid was eligible for 'khanship'.26

The Achilles heel of the empire was the succession process for the supreme office of khan as it generated internecine wars, but the Chinggisid lineage remained the backbone of the Mongol regime and kept its distinctive status several centuries after the collapse of the empire.

\title{
1.1.2 Mechanisms of Succession in the Old Mongol Empire
}

The official sources described the Mongol empire as a 'family-owned empire'. They emphasized the unity and solidarity of the Chinggisid kin. ${ }^{27}$ The khan's idealized extended family, living in peace, became a metaphor for the empire:

\begin{abstract}
Although authority and empire are apparently vested in one man, namely him who is nominated Khan, yet in reality all the children, grandchildren and uncles have their share of power and property; a proof whereof is that the World-emperor Mengü Qa'an (1251-1259) in the second quriltai apportioned and divided all his kingdoms among his kinsfolk, sons and daughters, and brothers and sisters. ${ }^{28}$
\end{abstract}

Yet, to define 'the Chinggsids' is not a simple task. The name did not carry the same social and political implications at the end of the fourteenth century when their primacy in Asia was challenged as it had in the thirteenth century when they were at the peak of their power. Thus, how to circumscribe this moving group? And what was exactly the connection between the imperial offices the elite members held, especially the highest offices of khan and great khan, and their position within the kin group?

26 On the persistence of the Chinggisid prestige, see Robert McChesney, "The Chinggisid Restoration in Central Asia: 150o-1785', in: Nicola Di Cosmo, Allen Frank, and Peter Golden, eds., The Cambridge History of Inner Asia: The Chinggisid Age (Cambridge, 2009) 277302 .

27 Recent scholarship has shown that the idealized family, the importance of the patrilineal filiation, and the role of the khan's wives in politics appeared as well in the illustrations of the imperial sources: Anna Caiozzo, 'La conception de la famille d' après la copie illustrée du Ğāmi' al-tawārīh de Paris (BnF, supplément persan 1113)', Annales Islamologiques 47 (2013) 83-112.

28 Juvayni, Genghis Khan: The History of the World Conqueror, 42. 
In theory, 'the sons', which meant the princes of the blood, descendants of Chinggis Khan through the male line, could all claim the position of great khan. ${ }^{29}$ They belonged to the old Mongol lineages of the Qiyat-Borjigid and shaped a new branch called 'the golden lineage' (altan urugh). The Mongol rulers chose their successor during their lifetime from among their sons and grandsons. Yet, these nominations were usually not successful. Great Khan Ögödei nominated his grandson Shiremün to succeed him, but Shiremün never ruled. Güyük, the eldest son of Ögödei, was chosen instead. After him, Möngke, son of Tolui, was elected even if he was obviously not the choice of Güyükas this meant that Güyük's own direct descendants were set aside from the throne. ${ }^{30}$ In fact, the election of a new great khan was the conclusion of a lengthy negotiation process, which ended after a quriltai, a great assembly, had taken place. A quriltai lasted for months as it required 'the full attendance by the political elite' to give decisions legal force. ${ }^{31}$ Only, then, when all the Mongol leaders, including relatives by marriage, influential people from outside the golden lineage, and senior widows, gathered together, was the khan legally elevated to the throne. ${ }^{32}$

During the interregnum periods the most influential wife of the deceased khan was often designated as regent - in fact co-regent with other male members of the family—, like the khatuns Töregene (the second wife of Ögödei) and Oghul Qaimish (Güyük's first wife). ${ }^{33}$

When we look at the elections from Ögödei to Kublai, we see patterns behind the practices of succession: being a male descendant of Chinggis Khan; having strong support among other important members of the elite; being able to take mature decisions and to fight, if necessary, on the battlefield. Normally, only princes who had lost their father were eligible. And there was an additional important restriction that historians often overlook:

29 Mongols kept the official titles simple and straightforward, 'the sons' appeared in a wide range of sources: in Persian pisar, in Turkic oghul, oghlan, and in Mongolian köbe’ün.

30 Timothy May, 'Commercial Queens: Mongolian Khatuns and the Silk Road', Journal of the Royal Asiatic Society 26 (2015) 89-106; Anne F. Broadbridge, 'Marriage, Family and Politics: The Ilkhanid-Oirat Connection', Journal of the Royal Asiatic Society 26 (2015) 121-135.

31 According to Hodous's recent study, 'The principle function of a quriltai seems to have been in formally granting legitimacy to a new person or to new decisions'. Florence Hodous, 'The Quriltai as a Legal Institution in the Mongol Empire', Central Asiatic Journal $56(2012 / 13) 87-102,91$.

They were also elevated on a felt rug, see Ron Sela, Ritual and Authority in Central Asia: The Khan's Inauguration Ceremony (Bloomington, 2003).

May, 'Commercial Queens: Mongolian Khatuns and the Silk Road', 89-106. 
According to the custom of the Mongols the rank of the children of one father is in proportion to that of their mothers, so that the child of an elder wife is accorded greater preference and precedence. ${ }^{34}$

What Juvayni meant by 'elder wife' needs to be clarified as the question of the rank of the khatuns, queens, was crucial. The Mongols considered marriage as a political partnership and put no legal restriction on the number of wives a man could have. Men of high status had usually between two and four chief or elder wives; likewise, Mongol rulers had many spouses, but few of them were actually chief wives. The old genealogies listed only the most important khatuns and concubines who often had their own courts. ${ }^{35}$ Secondary wives and concubines did not have their own courts but were under the control of the chief wives. ${ }^{36}$

The criteria for recognition as chief wife were manifold: seniority in marriage (the first wife); seniority in age (the eldest wife); ${ }^{37}$ the pedigree of the khatun (the Qiyat-Borjigid had preferential in-laws groups, the Qonggirat, the Kereit, and the Oirat, that were considered as the best lineages for Mongol women); her personal network (her sisters', brothers', and in-laws' positions); and finally, her personal affinities and choices. ${ }^{38}$ The status of a khatun resulted from all these ingredients. Setting an order of precedence for wives did not reduce the number of throne pretenders, but it gave them a ranking. Yet the ranking did not prevent all conflicts.

34 Juvayni, Genghis Khan: The History of the World Conqueror, 40.

35 Mu'izz al-ansāb. Proslavljajuščee genealogii, A.K. Muminov, ed., trans. Sh. Kh. Vokhidov (Almaty, 2006) 38. The author indicates that Jochi's concubines, like his wives, were too many to be remembered and listed.

36 Bruno De Nicola, 'The Queen of the Chaghatayids: Orghīna Khātūn and the Rule of Central Asia', Journal of the Royal Asiatic Society 26 (2016) 107-120.

37 It is important to note that a second marriage usually gave a khatun higher socio-political responsibilities than her co-wives. Besides, levirate was a common practice under the Mongols, see Holmgren's classic study, 'Observations on Marriage and Inheritance Practices in Early Mongol and Yuan Society'; and Broadbridge's recent contribution, 'Marriage, Family and Politics: The Ilkhanid-Oirat Connection', 121-135.

38 On the domestic circles of the Mongol rulers and the key role played by mothers, wives, concubines, and nurses, see Bruno De Nicola, 'The Role of the Domestic Sphere in the Islamisation of the Mongols', in: Andrew C.S. Peacock, ed., Islamisation. Comparative Perspectives of History (Edinburgh, 2017). 
Jochi's ulus - in the sense of his extended family and dependent peopleestablished itself in the western territories of the empire, originally the basin regions of the Irtysh, the Syr-Daria, the Ural, and the Volga. Jochi had more than eight wives; three of them were considered as chief wives. If we add the numerous concubines and the children, Jochi's family was already quite a huge group of more than fifty people. ${ }^{39}$ Depending on the sources, he had between fourteen and forty sons. Eleven of them would eventually become founders of lineages, and only four of these lineages became ruling lineages in the long run. ${ }^{40}$

When Jochi died, two of his sons were in a position to rule: Orda (d. 1251) and Batu (d. 1255). Batu succeeded his father by order of Chinggis Khan, but Jochi's territories and army were divided between them. Orda's descendants ruled the eastern lands and Batu's descendants the western lands. Until the bulqaq - as the contemporaries called the dynastic crisis of the 136os-1370seleven khans succeeded each other on Batu's throne while about eight khans ruled successively after Orda-perhaps a sign of a slightly longer life span.

Orda had inherited the core of the original part allotted to Jochi. His horde was called the left wing, and his descendants 'the princes of the left hand'. Their territory stretched from Lake Balkhash to the lower Volga and created a buffer zone between the Golden Horde and the Chagatayid khanate. The princes of the left hand played a role within the political life of both khanates. Yet the supremacy of Batu's offspring over Orda's remained uncontested until the extinction of Batu's lineage at the end of the fourteenth century. ${ }^{41}$

Batu was one of the most influential characters of the Mongol Empire, second only to the great khan. He controlled the Qipchaq steppes, the Bulgar kingdom, and the Russian principalities; most of all, he was in a position to achieve the conquest of Anatolia. Since their defeat at Köse-dağ in 1243, the Seljuqs of Rum had submitted to the Mongols. Batu's leading role in the western campaigns, after the death of both Jochi and Chinggis Khan, may explain his dominant position in the Golden Horde. His offspring kept control of northern Caucasus, eastern Anatolia, and the region north of the Black Sea including Crimea: all territories lying 'as far in that direction [North-West] as the hoof of

39 Mu'izz al-ansāb. Proslavljajuščee genealogii, 38 .

40 István Vásáry, 'The Jochid realm, the western steppes, and eastern Europe', 67.

41 On the rule of Orda and his descendants, see Thomas Allsen, "The Princes of the Left Hand: An Introduction to the History of the ulus of Orda in the Thirteenth and Early Fourteenth Centuries', AEMA 5 (1985 [1987]) 5-40. 
Tartar horse had penetrated'. The formation of the Golden Horde was deeply connected with the Mongol's push towards the North-West.

When Batu died, Great Khan Möngke chose the eldest son of Batu, Sartaq, to succeed his father. It was apparently also Batu's wish to have his son on the throne instead of his brother Berke. To be officially recognized as Batu's successor, Sartaq had to go to the great khan's court in Mongolia. He died on his way back. Consequently, Möngke ordered that Sartaq's son, Ulaqchi, would become khan. Only after Ulaqchi died, in 1257-1258, could Berke ascend the throne. He was Batu's half-brother. The fact that the great khan originally ruled Berke out as successor to the throne has a twofold explanation. Berke's mother was a princess of the Muslim royal family of the Khwarezmshah, while the mothers of Orda and Batu were Qonggirat princesses. In the Mongol world, the Qonggirat women enjoyed higher status than the Central Asian princesses; so Berke had a lower position within the family. Besides, the succession plan was clearly to favour Batu's offspring from his chief wives and to keep away his brothers' lineages. The great khan was keen to control the number of pretenders and to limit the lateral options. This explains why, when Berke passed away, after ten years of rule, Möngke-Temür, who was Batu's grandson, was elected khan in lieu of one of Berke's descendants. Being a direct descendant of Batu remained the rule. ${ }^{42}$

During the period of the unified Mongol empire (c. 1206-126o) the great khan nominated the khans-while the great khan himself was elected by the nomadic elite gathered in quriltai. When the Golden Horde became independent, it inherited its succession patterns from the old empire. Khan Möngke-Temür (r. 1267-128o) was elected during an internal assembly, within the Golden Horde, while his predecessors used to be selected by the great khan. After him, the practice of the quriltai was maintained, and if the khan's decision for his own succession was valued, it was not necessarily followed. The Jochid elite was strong enough (financially and in legitimacy) to select their own can-

42 On Berke's rule and conversion to Islam, see Jean Richard, Jean, 'La conversion de Berke et les débuts de l' islamisation de la Horde d' Or', Revue des Etudes Islamiques 35 (1967) 173184; István Vásáry, “History and legend” in Berke Khan's conversion to Islam', in: Denis Sinor, ed., Aspects of Altaic Civilization II (1990) 230-252; Devin DeWeese, Islamization and Native Religion in the Golden Horde: Baba Tükles and Conversion to Islam in Historical and Epic Tradition (University Park, PA, 1994) 83-86; Marie Favereau, 'Comment le sultan mamlouk s' adressait au khan de la Horde d' Or. Formulaire des lettres et règles d' usage d'après trois manuels de chancellerie (1262-v. 1430)', Annales Islamologiques 41 (2007) 6264. Ulaqchi was a son of Batu or Sartaq's son. Only very few sources mention him. 
didate. Möngke-Temür, for instance, was supported by the beglerbeg Nogay, the chief emir of the ulus. This could also lead to situations where the khans were not de facto rulers; on many occasions, the ulus begs ruled in actuality. Yet the begs did not bear the title 'khan'. They were able to use the title 'güregen', Chinggisid son-in-law or bride-groom, only when they had married a Chinggisid princess. ${ }^{43}$ Jochid independence was further asserted by Khan Möngke-Temür when he started to mint coins under his name; previously they had been minted under the name of the great khan or in association with him.

In the 1360 s, the system temporarily collapsed. Batu was the founder of the most prestigious lineage in the Golden Horde. Birdi-Bek (r. 1357-1359) was considered as the last ruler descending from Batu: 'After him [Birdi-Bek] the lineage of Saïn khan [Batu] stopped. The Uzbeks have a proverb which says: "the neck of the camel was cut in the person of Birdi-Bèk".44

A range of reasons can explain the end of the lineage: political assassination and blood feud; female regency; the end of the Mongol commonwealth; mass deaths due to the plague, to alcoholism, and perhaps to consanguinity. The crisis lasted more than ten years. Political assassination, which occasionally occurred in the Golden Horde, reached its peak at this time; yet it cannot be taken as the cause of the dynastic crisis. It was more a sign of it. The dysfunction of the institution of khanship was already visible during BirdiBek's rule: in 1358-1359, four khans were ruling at the same time as their coins, minted in various cities of the Golden Horde, show. ${ }^{45}$ Obviously, being a direct descendant of Batu was not enough to rule as a legitimate khan. The consensus of the begs and the support of the beglerbeg were crucial for a candidate to be successful and to stay on the throne.

Actually, Birdi-Bek, eventually replaced by his brother Qulpa, was not the last Batuid. Yet, he was the first khan who could not impose himself as a unifying ruler and prevent co-rulers from claiming their rights to Batu's throne.

43 On the title and status of güregen 'son-in-law' during the thirteenth-fourteenth centuries, see Ishayahu Landa, 'Imperial Sons-in-law on the Move: Oyirad and Qonggirad Dispersion in Mongol Eurasia', Archivum Eurasiae Medii Aevi 22 (2016) 161-197.

44 Abu l-Ghazi Bahadur Khan, Histoire des Mongols et des Tatares, trans. P. Desmaisons, ed. (Amsterdam, 1970 [1825]) 186. The author was a Jochid Khan ruling in Khiva in the midseventeenth century.

45 On the bulqaq, see Yu. E. Varvarovskij, Ulus Dzhuchi v 60-70-e gody XIV veka (Kazan, 2008); and István Vásáry, 'The Beginnings of Coinage in the Blue Horde', Acta Orientalia Academiae Scientiarum Hung. 62, no. 4 (2009) 371-385. 
The major consequence of the bulqaq was not merely the extinction of the main lineage of khans, but a profound change in the geopolitical landscape. Descendants of Jochi from secondary matrimonial lines were accepted as candidates for the throne. In the 1370s, for instance, Urus Khan became head of the left wing. His lineage went back to an obscure son of Jochi, Toqa-Timur, whose mother was a concubine of Merkit origin. The western lands passed under the control of the beglerbeg Mamaq the Qiyat (c. 1361-1380), a 'son-in-law' married to Birdi-Bek's daughter. Both Urus and Mamaq remained at the head of this dual Horde until their military defeats at the hands of Toqtamish Khan, another descendant of Toqa-Timur, supported by Timur. This resolution demonstrates the strength of the Golden Horde's dynastic system based on multigeniture. It fuelled conflicts at times, but it insured that there was no shortage of throne contenders should a lineage become extinct.

If we look at the succession process in the Golden Horde until the end of the fourteenth century, we can see that there were rules to restrict access to the throne. To be eligible, the candidate had to be a descendant of Jochi, through the male line. Most of the time, the sons of the preceding khan were favoured over his brothers and nephews, and there was no clear principle of seniority. In any case, the candidate had to be mature enough to rule, and we know no case of an 'infant khan'.

The marriage patterns were the same as in the old Mongol empire: the most high-ranking khatuns were of Oirat, Qonggirat, and Kereit origins, and the ranking of the sons was established according to their mother's status. Khan Berke, as we saw, is a case in point. The Jochid khans, be they Muslim or Buddhist, had at least four wives and a certain number of concubines. Yet the status of the chief wife was very high, and she dominated the other wives. Accordingly, the khan's mother was highly respected and had significant financial power. The khatun Taytoğll-Taidula, in Russian-is a good example. Chiefwife of Özbeg (r. 1313-1341), mother of the khans Tini-Beg (r. 1341-1342) and Jani-Beg (r. 1342-1357), grandmother of Berdi-Beg (r. 1357-1359) and Qulpa (r. 1359-1360), she dominated the Golden Horde for twenty years. She had her own revenue-based on the commercial taxes paid by the Italian merchantsand issued several diplomas of tax exemption especially to the Russian Orthodox Metropolitan. ${ }^{46}$ She played a seminal role in supporting her favourite son Jani-Beg and other pretenders before she was murdered. The Muslim begs were strongly against the option of having a woman on the throne, and the

46 See Marie Favereau, 'Istochniki po istorii Zolotoj Ordy: novye perspektivy izuchenija', Golden Horde Review/Zolotoordynskoe obozrenie 1 (2016) 45. 
possible election of a female khan generated struggles between the begs during the time of the bulqaq. Taytoğlı was the last female regent of the Golden Horde.

In the last quarter of the fourteenth century, the collapse of the three other imperial formations and the end of the Mongol commonwealth had serious consequences for the Golden Horde. The pretenders' pedigree became key to their throne strategy leading to increasing genealogical speculations. The khatuns' ranking was still linked to the hierarchy of their sons, but their agency had become reduced. Up until then, the khans had married Qonggirat and Kerait princesses who had close connections in Mongolia, China, and Iran. In the second half of the fourteenth century, the khatuns' personal networks contracted, as did their political and economic agency. One of the political responses to the crisis was the evolution of the khanship institution.

\section{$1.2 \quad$ From Genealogy to Dynasty: Dynastic Concepts}

In the fifteenth century, the rise of three competing Jochid lineages, the Ordaids, the Shibanids, and the Toqa-Timurids, implied territorial redistributions and migrations of nomads. The rise of these secondary lineages caused also an inflation of pretenders. Because the hierarchy between them was no longer regulated and the competition was harsher than before, the candidates' genealogical claims became key to their throne strategy. The 'internal competition' among the descendants of Toqa-Timur and Shiban, as well as the 'external competition' with the Timurids, triggered the genealogical speculations. It was already common practice to use genealogy as a form of legitimization. More peculiar is its systematic use among Islamic rulers in Eurasia after the Mongol conquests. Tables and genealogies combined with historical writing appeared frequently at that time, not only in the Islamic lands but in Western Europe as well. Genealogical trees and portraits in miniature developed markedly in the thirteenth and fourteenth centuries as an answer to socio-political disruptions and in response to the tastes of the new ruling elite. ${ }^{47}$

47 Ilker Evrim Binbas, 'Structure and Function of the Genealogical Tree in Islamic Historiography (1200-1500)', in: Ilker Evrim Binbas and Nurten Kilic-Schubel, eds., Horizons of the World: Festschrift für Isenbike Togan (Istanbul, 2011) 465-544, has pointed out that the systematic use of genealogical trees in the Islamic world began in the Mongol period in Iran. We should add that this occurred in Central Asia and Egypt as well (it was not by chance that the Mamluks sent a genealogy of the Abbasids as a gift to Khan Berke). For a broader picture on texts composed in graphic form, combining narrative, genealogies, and tables, in the Islamic historiographical tradition, see Denise Aigle, "The Historical taqwīm in Muslim East', in: Denise Aigle, The Mongol Empire between Myth and Reality. Studies in 
For the Muslim historians of the post-conquest world, genealogy was also a powerful intellectual tool to rethink the place and the role of the dar alislam, the abode of Islam, in world history. Representations of kin relationships offered new graphic opportunities and were used as a sort of framework for complex narratives: a backbone that helps not only to ramify separated histories but also to visualize them. From a 'reminder' added to a larger work, it became a genre in itself. ${ }^{48}$ The connection between genealogy and political legitimacy, the combination of interest in lineages and historical context, and the superposition of family and ruling issues led these historians to develop what we can call dynastic concepts.

To the great intellectuals of the time, such as Rashid al-Din (1247-1318) and Ibn Khaldun (1332-1406), who both intended to include genealogical trees in their monumental works, genealogical succession had an organizational function in the way they conceptualized history. ${ }^{49}$ In their works, the distinction between dynastic construction and family genealogy appeared clearly: they created dynasties by cutting up the genealogies along the course of the human leadership, which was the historical course they have laid out.

If we consider the period when the Jochids were in power, from the midthirteenth to the mid-sixteenth century, our main source of information on their dynastic concepts comes from books patronized by Ilkhanid and Timurid rulers who were in competition with the khans and claimed the same origin and the same rights to rule the post-Mongol empire. The boom in royal genealogies and the development of genealogical representations in this period are not due to chance. Mongols were obsessed with keeping alive the memory of their lineages, especially 'the golden lineage'. Rashid al-Din noticed that the science of genealogy ( ilm al-nasab) assumed great importance under the descendants of Chinggis Khan: ${ }^{50}$

Anthropological History (Leiden, 2014) 89-104, 96-97. On the appearance of miniatures in Islamic manuscripts as a Mongol fashion, see Charles Melville, 'The Royal Image in Mongol Iran', in: L. Mitchell and Ch. Melville, eds., Every Inch a King: Comparative Studies on Kings and Kingship in the Ancient and Medieval Worlds (Leiden, 2013) 343-369. On the European context, see Gabrielle M. Spiegel, The Past as Text. The Theory and Practice of Medieval Historiography (Baltimore and London, 1999).

48 Binbas, 'Structure and Function', 487.

49 Binbas, 'Structure and Function', 486.

50 According to Ibn al-Tiqtaqa, the science of genealogy is specific to the Arabs, who keep their genealogical records. The Iranians (al-Furs) don't keep them and don't conduct any research on genealogy: Binbas, 'Structure and Function', 483. 
The many clans and tribes descended from Alan Qo'a [the ancestress of the Chinggisids] are so numerous that if the individuals were to be counted they would exceed a million, yet each of them has a clear and unambiguous family tree, for it is a Mongolian custom to preserve one's relationship to one's fathers and forefathers, and every child born is taught and inculcated with his genealogy like all others in that nation. There is not one among them who does not know his tribe and lineage. Nations other than the Mongols do not have such custom-except for the Arabs, who also keep their genealogy. ${ }^{51}$

Rashid al-Din had an immense influence on later historians, and his work had a strong impact on the court chronicles the successors of the Golden Horde's khans patronized. ${ }^{52}$ His first volume of the Jami' al-Tavarikh included genealogical trees, the largest one being the one devoted to the descendants of Jochi. The author intended to add miniature portraits of the khans depicted in squares, of their wives depicted in circles, and of their children. The concubines and commanders (emirs) of each khan were listed under his name. ${ }^{53}$ Moreover, Rashid al-Din conceived the third volume of the Jami' al-Tavarikh, the Shu'abi panjgana, as a unique genealogical tree combining the lineages that outlined his world history. He claims to have invented a new and easier format to illustrate the complexity of the genealogical ramifications. ${ }^{54} \mathrm{He}$ expressed the continuum of human history through a single line - a kind of tree trunk - that goes from Adam to the ruler to whom the book was dedicated. ${ }^{55}$ The section

51 Rashid al-Din, Rashiduddin Fazlullah's-Jami'u't-tawarikh. Compendium of Chronicles: A History of the Mongols, trans. W.M. Thackston (Cambridge, 1998) 116. He asserts again further in his book, on p. 124: 'Now each of those clans numbers twenty to thirty thousand households and the number of men and women may reach a hundred thousand individuals. This must not be attributed to exaggeration, for it has been the Mongols' custom from ancient times on to keep their origin and genealogy, and since they have no religious community or religion in which to instruct as others do, fathers and mothers inculcate into every child that is born their tribes and genealogy. They have maintained this as a constant rule, and even now the rule is of great importance for them. The Arabs also do this.'

$5^{2}$ For instance, the chronicle of Abu l-Ghazi Bahadur Khan, quoted earlier in this chapter: half of it relies on Rashid al-Din's work.

53 Binbas, 'Structure and Function', 488-489. Miniatures are unfortunately missing in most copies.

54 On this claim, see Binbas, 'Structure and Function', 485-487.

55 Binbas, 'Structure and Function', 494: 'The sense of historical continuity is achieved by a single line from Adam to Ghazan khan—this line the author names "pillar of the lineage" 
on the genealogies of the Mongols (Shu'ab-i Mughul) goes from Alan Qoa, the ancestress of the Chinggisids, to Ghazan (r. 1295-1304). ${ }^{56}$

A century later, under the Timurids, Rashid al-Din's work remained a major source of inspiration and knowledge for Central Asian court historians. Around the years 1417-1427, several chronicles were written in Herat at the court of Shahrukh (r. 1405-1447), son and successor of Timur. This creative impulse was obviously triggered by the competition between Shahrukh's sons. Yet the dynastic claims of Jochi's descendants were also at stake. The earliest Timurid genealogical tree, probably written between 1405 and 1409 by Husayn b.'Ali Shah's, emphasized Jochi's line down to Khan Jani-Beg, while the descendants of Chagatay and Ögödei were not even mentioned in the Chinggisid lineage. Indeed, the author's patron, Khalil Sultan, was a grandson of Janibek's daughter. The descendants of Toqa-Timur were excluded as well. They were at that time the fiercest enemies of the Timurids. ${ }^{57}$

The most famous genealogical work produced in this context is the Mu'izz al-ansab. Completed in 1426/27, it was dedicated to Shahrukh, and its original author was most likely Hafiz-i Abru. ${ }^{58}$ Instead of adopting Rashid al-Din's graphic codes, he represented female figures with squares and male figures with circles - if they were in power, their circles were bigger; each son who ruled in his own name and had children was depicted with a parallel line. Under the name of each khan, the list of his commanders (emirs) was written on the right side, while the wives and concubines of the same ruler appeared on the left side. The author gave also basic information on the family origins of the

(the 'amud al-nasab).' I notice that Ibn Khaldun used the same terminology. See also Aigle, 'The Historical taqwìm in Muslim East', 94.

$5^{6}$ In the Persian version of the Jami' al-Tavarikh, the Turkic term urugh (lineage) is used to refer to the descendants of Chinggis Khan; kutub-i ansab and shu'ab, shu'ba (lit. branches) can be translated as genealogies; aqvam as people; mushajjar as genealogical tree.

57 Binbas, 'Structure and Function', 509-514.

$5^{8}$ According to A. Zeki Velidi Togan, 'The Composition of the History of the Mongols by Rashīd al-Din', Central Asiatic Journal 7, no. 1 (1962) 68-69, followed by Binbas, it was probably intended to be the last part of Hafiz-i Abru's book, the Majma' al-Tavarikh. In the text, it is said that the information about the Mongols was taken from a work called Tarikh-i salatin-imughul, which was most probably Rashid al-Din's Shu'ab-i panjgana. The work is nevertheless different: the Shu'ab-i panjgana was intended to be 'a genealogical representation of the mythical past of humankind', while there is no such intention in the Mu'izz al-Ansab. Binbas, 'Structure and Function', 517-521. The academic literature on the $\mathrm{Mu}$ 'izz is too extensive to be listed here. A thorough introduction to the work can be found in Muminov's edition: Mu'izz al-ansāb. Proslavljajuščee genealogii, $5^{-16}$, where Muminov shows that the text, even if initially composed by Hafiz-i Abru, was a collective work. 
women, as well as the major events of the khans' lives and sometimes even the dates of the khans' reigns.

The work was divided into two main sections: the first one was devoted to the Jochids, the second one to the Timurids. According to the author, Jochi had eighteen sons. Although they were still the enemies of Timur's descendants, the branch of the Toqa-Timurids was included and found its place among the other Jochid lineages. What was the political goal in this case? Two points can be made. First, the fact that there was no selection between the Jochid lineages meant that there was no primacy among them. They appeared all at the same level: eleven lineages as eleven dynastic tracks. The Toqa-Timurids who were claiming the first place are not emphasized. Second, the book was supposed to conclude with the four sons of Shahrukh, glorified as the direct and rightful successors of the Chinggisids and of the Timurids. ${ }^{59}$ Shahrukh's sons appeared as the genealogical completion of all the lines, including Jochi's. They were to be the future of the Jochids.

From the end of the fourteenth century onwards, Toqa-Timur's line became dominant in the Golden Horde and in its successor khanates. The Great Horde $^{60}$ and the khanates of Kazan and Qasimov were all 'founded' by ToqaTimurids. Qasim - first khan of Qasimov-was the brother of the khan of Kazan. The Giray khans of Crimea had the same ancestors. They had close ties with the most powerful nomadic confederation of the time, the Manghits. ${ }^{61}$ It was therefore not by chance that after marrying the khan of Kazan the daughter of the Manghit beg married Mengli-Giray (c. 1445-1515). But, in the same period, Abu al-Khayr (r. 1429-1468), a descendant of Shiban, succeeded in establishing his khanate in the northern lands of the Golden Horde. The Shibanids, another secondary line that became very strong in the fifteenth century, became the Toqa-Timurids' major competitors. ${ }^{62}$

59 The end of the genealogical tree differs according to the date of the manuscript and to the identity of the copyist's patron. The oldest copy we have seems to date back to the sixteenth century. Binbas, 'Structure and Function', 517. The primacy of Shahrukh's four sons is expressed in the poem at the end of the introduction. Binbas, 'Structure and Function', 519.

6o The Great Horde was in fact the core area of the Golden Horde, the region of Saray. In the 143os, it covered the lower Volga valley and the western steppes up to the Dnieper.

61 On the Manghits, also known as the Nogays, see the seminal work of Vadim V. Trepavlov, Istoriia Nogaiskoj Ordy (Moscow, 2002).

62 Shiban or Shayban, a son of Jochi who played a significant role during Batu's lifetime. 
Abu al-Khayr controlled the south of the Ural mountains and the Siberian region of the Tobol valley, including the important cities of Sibir-Isker on the Irtych river, near Tobolsk, and Tiumen'. In 1430-1431, he conquered the Khorezm and the Jochid capital cities of Sighnak and Urgench. He married the daughter of Ulugh-Bek, the grandson of Timur. Under the leadership of Muhammad Shibani Khan (c. $\left.145^{-1510}\right)$ his descendants were to be the greatest rivals of the Timurids in Central Asia.

In comparison with the Toqa-Timurids, the Shibanids were 'genealogically isolated'. In the fifteenth century the huge majority of the khans, from the Crimea to the Volga Valley, were descendants of Toqa-Timur. To enhance the reputation of their lineage, the Shibanids (later called Uzbeks) were most active in patronizing works that praised their origins like the Shaybani name. They developed what we can call the theory of the four hordes: the Blue, Grey, White, and Golden Hordes. In this historical-epic conception of the past, only four sons of Jochi were recognized as founders of khans' lineages: Orda, Batu, ToqaTimur, and Shiban. Each of them had a horde - the Shibanids having the Grey one. The names were given to the hordes according to the steppe colour system for the cardinal directions in which grey or black means north, blue means east, red means south, and white means west, while yellow or gold was used for the centre (which was also the attribute of the imperial tent). The division into hordes was another form of dynastic representation, more directly connected to the Turk and Mongol nomadic world than the Indo-Persian miniatures. In any case, the epic format had the advantage of being more spacious than the tree format. Not only did it give the genealogical speculations more room, but the lineages were developed as vignette stories and claims on territories could be combined with claims on ancestry. ${ }^{63}$

On the Shibanids, see Robert McChesney, 'Shībānī Khān' and 'Shībānīds', Encyclopaedia of Islam IX, New Edition (1997) 426-431.

63 The most striking example is the Chinggis name by Ötemish Hajji, which dated back to the mid-sixteenth century. See its partial edition: Utemish Khadzhi, Chingiz-name, trans. V.P. Iudin, Iu. G. Baranova, and M. Kh. Abuseitova, eds. (Almaty, 1992) 22-48. On the Blue and White Hordes, another most interesting source, composed in 1413-1414, is: Jean Aubin, Extraits du Muntakhab al-tavarikh-i Mu'ini (Anonyme d'Iskandar) (Tehran, 1957); On the steppe colour system for cardinal directions, see A.N. Kononov, 'Terminology of the Definition of Cardinal Points at the Turkic Peoples', Acta Orientalia Academiae Scientiarum Hungaricae 31, no. 1 (1977) 61-76. On the genealogical competition between the Toqa-Timurids and the Shibanids, and on the late Golden Horde and the rise of its successor states, see Marie Favereau, La Horde d'Or. Les héritiers de Gengis Khan (Lascelle, 2014) 210-229. 
When modern historians emphasize the progeny of the four sons of JochiOrda, Batu, Toqa-Timur, Shiban - they should not forget that this is a vision post hoc. There were not four ruling hordes in the thirteenth century, but only two - Batu and Orda's. As members of secondary lineages, the Shibanids and the Toqa-Timurids were very active in supporting the production of a hagiographical literature dedicated to their genealogical credentials. ${ }^{64}$ This literature has influenced the historical writing about the Golden Horde and its successors in Russia, Central Asia, and Europe. Geographical and genealogical divisions that are believed to date back to the thirteenth century reflect in fact the dynastic concept of the fifteenth century.

These forms of dynastic elaboration, produced in a court context, were intellectually speculative. They were historical and political — they addressed inside and outside audiences ${ }^{65}$ — but not juridical; they had no legal basis and, apparently, no legal effects. So in what ways did they reflect the practices of power? One of the main purposes of the dynastic construction was to validate current situations and hide dynastic problems such as political divergences, family divisions, state murders, and the real origins of rulers. Most significantly, such intellectual speculations had no influence at all on the practices of succession. Indeed, these books came a posteriori, to justify existing situations. They did not introduce new rules or new laws. They were meant to play an important role in the competition between rulers, and, even if their real impact on the notion of sovereignty is hard to evaluate, they worked as a legitimizing principle for succeeding generations. More than anything, they had an effect on the way a ruler was remembered by later generations.

As pointed out by scholars, in the section devoted to the Timurids, the $\mathrm{Mu}^{\prime} \mathrm{izz}$ al-ans $\bar{a} b$ mirrored the formal organization of their imperial administration. ${ }^{66}$

64 Interestingly the descendants of Orda, who obviously enjoyed more legitimacy, were less involved in the (re)-writing of their historical genealogy.

65 Under the Jochids, the Ilkhanids, and the Timurids, the authors presented their manuscripts to their patrons at the royal court. Their written contents and miniatures were seen by members of the local elites and, perhaps, guests invited to court. The scholarship on this topic is extensive, see, for example, Caiozzo, 'La conception de la famille d' après la copie illustrée du Ğāmi' al-tawārīh de Paris', 84-87; Eleanor Sims, 'The Illustrated Manuscripts of Firdausi's Shahnama Commissioned by Princes of the House of Timur', Ars Orientalis 22 (1993) 48-54; Sheila Blair, 'Timurid Signs of Sovereignty', Oriente Moderno 15, no. 2 (1996) 551-576; Michele Bernardini, Mémoire et propagande à l'époque timouride (Paris, 2008); Anna Caiozzo, 'Propagande dynastique et célébrations princières: mythes et images à la cour timouride', Bulletin d'études orientales IX (2011) 177-201; Gabrielle van den Berg and Charles Melville, eds., Shahnama Studies II: The Reception of Firdausi's Shahnama (Leiden and Boston, 2012).

66 Beatrice Manz, Power, Politics and Religion in Timurid Iran (Cambridge, 2003) 79, quoted 
The part on the Jochids, though less detailed, expressed a similar vision of the socio-political division at the core of the Horde. The way this genealogy is displayed shows how the khans were part of a regime that included khatuns, concubines, and ulus begs or emirs. Our hypothesis is that all together they created 'the dynasty'.

\subsection{Steppes Politics: The Role of the Begs}

The begs played a crucial role in the government of the Golden Horde. In 1263, Khan Berke wrote to the Mamluk Sultan Baybars 'we have all converted to Islam, ${ }^{67} \mathrm{He}$ added a list of several begs, military commanders, who had allied with him. Indeed, the political body of the Golden Horde was made up of the princes of the golden lineage and the military commanders who were the chiefs of tümen. ${ }^{68}$ Some of them created new lineages, and their descendants were privileged and treated as new elite members. In the introductory protocol of the yarliks, imperial orders issued by the khan's chancellery, the begs appeared right after the princes. ${ }^{69} \mathrm{In}$ the fourteenth-fifteenth centuries, they became the heads of the 'ruling tribes' with their own lineages.

The ruling tribes were a range of well-identified social groups that had names as well as taboos, mottos, and probably their own histories that circulated orally.70 They were the Qonggirat, Qiyat, Qatay, Manghit, Saljut, Shirin, Barïn, Arghïn, and Qipchaq. The heads of these groups were part of the governing council, an institution that came from the Chinggisid keshik, and bore

in Aigle, 'The Historical taqwīm in Muslim East', 96: 'the two sides of government are separately listed; first come the emirs, almost all of whom were Turco-Mongolian, then other offices, and near the end of the list we have sections for Persian and Turkic scribes'.

67 Baybars al-Dawadar, Zubdat al-fikra fì ta'rīh al-hiğra, Donald Richards, ed. (Beyrouth and Berlin, 1998) 82.

68 Originally a tümen was a military unit of 10,00o men. After the conquest it became a military-administrative unit that coincided with a defined territory. On the term itself and its evolution in a Jochid context, see: G.A. Fedorov-Davydov, Obščestvennyj stroj Zolotoj Ordy (Moscow, 1973) 122-124.

69 For instance in Khan Timur Qutluq's yarlik (1398), the introductory protocol says: 'To the princes of the right wing and the left wing, to Edigü who stands at the head of the tümen; to the begs of Thousand, Hundred and Ten' (Marie Favereau's translation). The original text is available in: Vasilij Radlov, 'Jarlyki Toktamyša i Temir-kutluga', Zapiski Vostočnago Otdelenija Imperatorskago Russkago Arxeologičeskago Obščestva 3 (1888) 1-40.

70 On the ruling tribes and their role in the administrative and political organization of the Golden Horde, see Uli Schamiloglu, 'The Qaraçi Beys of the Later Golden Horde: Notes on the Organization of the Mongol World Empire', Archivum Eurasiae Medii Aevi 4 (1984) $283-297$. 
the titles of beg, emir, and noyan. ${ }^{11}$ Together with the beglerbeg, they not only decided on war and diplomacy, but also elected the khan. The ulus begs acknowledged the khan's primacy because he was a descendant of Chinggis Khan's eldest son. Yet, to rule effectively a pretender had to associate himself with powerful begs. They supported him and, in case of failure, deposed him.

In the official documents of the Golden Horde the people as a social entity was called ulugh ulus 'the big people'. As we have seen previously, ulus is a Mongolian term meaning people, community, and nation. It was used to name the Mongol empire: Yeke Mongghol Ulus. The title ulus beg or ulus emir given to the nomadic chiefs implied that they ruled a unified people called ulus and that they fully associated themselves with the imperial project. These elite groups were shaped by a vertical principle of common descent, but also by a horizontal principle of alliances through marriage, adoption, trade partnership, and various forms of social clientelism. The most powerful begs were all güregen, 'sons-in-law'. It was a common practice that begs married Chinggisid princesses and Chinggisid princes married begs' daughters. The Qiyat, for instance, was Chinggis Khan's extended group, but also was Mamaq's group-Mamaq was the beglerbeg who took over the regency in the Golden Horde at the end of the fourteenth century. Because he was not a descendant of Chinggis Khan, he could not claim the title of khan, only that of 'son-in-law'; yet it allowed him to connect to the golden lineage.

Surprisingly, we know of no dynastic chronicles or official histories written for the khans. It seems that the Jochid leaders never patronized this kind of apologetic literature for themselves. This is a significant departure from other Chinggisid courts, such as the great khans and the Ilkhanids, where Juzjani, Juvayni, and Rashid al-Din, to name only the most famous writer-secretaries, produced major histories on the Mongol empire and its successors. The fact that the figure and position of vizir, or high-ranking secretary, was not as important in the Golden Horde as it was in these two other khanates might

71 In this context the Mongol word noyan, the Turkic word beg, and the Arabic word amir were synonymous. On the keshik, the khan's bodyguard, there is an extensive literature; classical references include: Christopher Atwood, 'Keshig', in: Christopher Atwood, Encyclopedia of Mongolia and the Mongol Empire (New York, 2004) 297-298; Peter Andrews, Felt Tents and Pavilions: The Nomadic Tradition and its Interaction with Princely Tentage (London, 1999) vol. 1, 281, 312, 324-325; Thomas Allsen, 'Guard and Government in the Reign of the Grand Qan Möngke, 1251-1259', Harvard Journal of Asiatic Studies 46, no. 2 (1986) 495-521; Charles Melville, 'The Keshig in Iran: The Survival of the Royal Mongol Household', in: Linda Komaroff, ed., Beyond the Legacy of Genghis Khan (Leiden, 2006) 135-164. 
explain this discrepancy. In the second half of the fourteenth century, Ibn Nazir al-Jayš, a Mamluk secretary in charge of diplomatic correspondence, noted 'when the vizir is not ruling, as in the ulus of Jochi, we give him the title alwaziri (ministerial) but never al-sahibi (rial) because this title is only given to the khan. ${ }^{72}$ Indeed, under the Jochids, the vizir was not ruling; the begs were the rulers. ${ }^{73}$

The lack of official written narratives sponsored by the khans or high-ranking members of the Golden Horde does not mean that histories about rulers and begs did not circulate orally. Epics and sagas written down in the sixteenth and seventeenth centuries included older material about the begs, khans, and princes of the house of Jochi. The qarï söz, 'the old word', as the nomads called their own historiography, gave a new perspective in which the khans' power was balanced by that of other political institutions. ${ }^{74}$ Even if they were written down after the Golden Horde collapsed, these texts are rich sources as they include older narratives. They gave a perspective from the begs' point of view: the power of the khan was balanced by the power of the begs, who were also ruling the Golden Horde.

According to one of these narratives, analysed by Mária Ivanics, when Chinggis Khan was a child, he had to escape his elder brothers. Ten begs decided to leave the elder brothers to find Chinggis and to invite him to be their ruler. Once they had found him, they made a cart, put Chinggis on it, then tied themselves to the cart and pulled it as if they were the horses. One of the begs was lame so he sat on the cart next to Chinggis and drove the begs-horses. In this metaphor of 'Good Government', the lame beg was the beglerbeg. It is said that he possessed the signet ring of Alan Qoa, the mythical ancestress of the Mongols, and that all the begs were of the lineage of Chinggis Khan's mother. ${ }^{75}$

72 Ibn Nazir al-Jaysh, Kitāb tatkîif al-tárīf bī-l-muștalah al-šarīf, Rudolf Vesely, ed., Institut Français d'Archéologie Orientale du Caire, Textes arabes et études islamiques 27 (Cairo, 1987) 12-13.

73 It seems that the title vizir (wazir) was not used under the Jochids; in their official documents they used bitikči, high secretary, instead of wazir.

74 'The oral historiography of the steppes' as Iudin coined it, see Iudin, Chingiz-name; also Devin DeWeese, Islamization and Native Religion in the Golden Horde. Baba Tükles and Conversion to Islam in Historical and Epic Tradition (University Park, 1994); Mária Ivanics and A. Mirkasym Usmanov, eds., Das Buch der Dschingis-Legende. Däftär-i Čingiz-nāmä (Szeged, 2002).

75 Mária Ivanics, 'Memories of Statehood in the Defter-i Genghis-name', Golden Horde Review 4, no. 3 (2016) 570-579. 
In this chapter, by revealing some of the mechanisms of the political regime that developed under the Mongols and the Habsburgs, we intend to challenge the notion of dynasty understood as 'a family in power'. In the case of the Mongols, the opposition between 'tribes' and 'khanate, state' needs to be questioned, as well as the assumed dichotomy between the Chinggisids, the imperial family, and the begs, the heads of the dominant social groups. The term tribe can be used to translate words such as qabila and taifa; it becomes a problem only when it implicitly or explicitly means that such groups were outside the state and opposed to the concentration of power that the khan supposedly embodied. As we saw, tensions among the steppe elites and the khans were healthy tensions between key political institutions and constituted the basis of the Golden Horde's political regime.

\section{2 The Spanish Habsburg Monarchy}

The section on the Jochids has shown how succession practices, dynastic concepts, and the social realities of dynastic rule interacted. It has also shown that our common view of Eurasian dynasties as mainly patrilineal lineages is too narrow. Sons-in-law (and their royal brides) and the collateral lines they engendered were excluded from the succession, but not from actual rule, and they were even integrated into the dynastic concept as presented, for instance, by the Muizz al-ansāb. Are these exclusively Mongol elements or do the European Habsburgs show similar features? The following section will discuss the development of the Habsburgs' succession practices, dynastic concepts, and ruling practices with an emphasis on the various actors and their mutual relationships.

\subsection{The Habsburgs: Origins and Successions}

The Habsburg dynasty originated in the Aargau region, on the border of modern Switzerland and South-west Germany, where they held a castle - the Habsburg-after which they were called counts of Habsburg from ca. 1100 CE onwards. The county was part of the Holy Roman Empire. The thirteenth-century Count Rudolph of Habsburg (1218-1291) was elected King of the Romans in 1273 and became the dynasty's first Holy Roman Emperor. During his reign as king he expanded the patrimony by granting vacant crown lands to his sons, namely the duchies of Austria and Styria. ${ }^{76}$ The family would take its most common name- the House of Austria - from these areas.

76 Benjamin Curtis, The Habsburgs: The History of a Dynasty (London, 2013) 18. 
Around $1500 \mathrm{CE}$, the Habsburgs became one of the most powerful dynasties in Europe. Many European patrimonies ended up in Habsburg hands through marriage and dynastic contingencies. In 1477, Maximilian (1459-1519), sole heir to the Austrian patrimonies, married Mary the Rich of Burgundy (1457-1482), heiress of the Low Countries. Their two children Margaret (1480-1530) and Philip (1478-1506) married the children of the Catholic Monarchs of SpainFerdinand of Aragon (1452-1516) and Isabella of Castile (1451-1504), from two distinct branches of the House of Trastámara - whose marriage had already joined Castile with Aragon and its Mediterranean empire. Although these marriages should have seen Margaret, who had married the crown prince, on the Spanish throne, Philip and his wife Joanna (1479-1555) unexpectedly became heirs to her parents after the deaths of Joanna's older siblings Juan (1497) and Isabella (1498), and nephew Miguel (1500). As a consequence, Philip and Joanna's sons Charles (1500-1558) and Ferdinand (1503-1564) stood to inherit extensive patrimonies from all four of their grandparents, consisting of the Low Countries, the Austrian archduchies, Castile and its growing overseas empire, and Aragon with its dependencies in Italy. The fruits of Habsburg marriage policies did not end there because in 1515 Philip and Joanna's children Mary $\left(15^{0} 5^{-1558)}\right.$ and Ferdinand married the king of Bohemia and Hungary and his sister respectively. ${ }^{77}$ When the king of Bohemia and Hungary died in 1526, Ferdinand - as his brother-in-law and husband of his only sibling Anne (1503-1547) — managed to be elected as the new king. By the sixteenth century, therefore, the Habsburg dynasty had acquired a huge empire and had in the process been divided into two branches descended from the brothers Charles and Ferdinand, usually known as the 'Spanish' and the 'Austrian' Habsburgs.

The Habsburgs were heirs to various dynastic traditions: the Babenberg dukes of Austria, the Valois dukes of Burgundy, the several Trastámara branches of the Iberian Peninsula, and others. Since dynastic practices in Europe were invariably influenced by bottom-up pressures exerted by subjects—elites and representative organs, who guarded local customary laws and held some power of negotiation in cases of contested successions-Habsburg succession practices were strongly embedded in their local contexts, and therefore varied from territory to territory. As we shall see, succession practices in Castile were quite different from those in the Austrian duchies. In the Low Countries and on the Iberian Peninsula, a pragmatic shift towards primogeniture emerged in

77 Enikö Spekner, 'Die Geschichte der habsburgisch-jagiellonischen Heiratsverträge im Spiegel der Quellen', in: Martina Fuchs and Orsolya Réthelyi, eds., Maria von Ungarn (15051558). Eine Renaissancefürstin (Münster, 2007) 25-46. 
the fifteenth century, while the Austrian duchies adhered strongly to partible inheritance. How did these various traditions come about and how could such different traditions be combined into a clear succession law among the Habsburgs?

The Habsburg dynastic conglomerate in the Holy Roman Empire was assembled during the period 1282/3-1363, starting when the first Habsburg Emperor invested his own sons with vacant imperial crown lands. ${ }^{78}$ The dynasty's custom was to award its patrimony jointly to all adult males; ${ }^{79}$ females and their descendants were generally excluded. ${ }^{80}$ But in practice the patrimony was divided among them because joint rule was 'programmed to be problematic'. ${ }^{81}$ Therefore, until the early seventeenth century, the Habsburg territories—-such as Inner Austria, Further Austria, Tyrol, Styria, Carinthia, and others-were routinely partitioned among several male members of the dynasty, in spite of regular efforts to institute primogeniture. Exceptionally, the dynasty produced only one male heir at the end of the fifteenth century (Maximilian I) who united all Habsburg territories in his own hands - creating a rather fleeting and illusory sense of unity. During Maximilian's reign, he tried to foster institutional unification, for instance by promulgating identical laws in his various territories and standardizing the procedures of the representative organs. ${ }^{82}$ Also, there were several attempts to create a kingdom out of the various territories, which would have implied their permanent union, but nothing came of this. In practice, the partitioning of the patrimony among male heirs was the guiding principle of Habsburg successions.

78 Christian Lackner, 'Das Haus Österreich und seine Länder im Spätmittelalter. Dynastische Integration und regionale Identitäten', in: Werner Maleczek, ed., Fragen der politischen Integration im mittelalterlichen Europa (Ostfildern, 2005) 273-301, 275.

79 Paula Sutter Fichtner, The Habsburgs: Dynasty, Culture and Politics (London, 2014) 45, 49.

80 The pre-Habsburg rulers of Austria, the Babenbergs, had been granted the right to observe female inheritance, the so-called privilegium minus of $1156 \mathrm{CE}$, but this was limited to one duke without sons. Jean Bérenger, A History of the Habsburg Empire 1273-1700, trans. C.A. Simpson (London, 2013) 35. The question was normally moot because of the existence of male heirs. The eighteenth-century emperor Charles vi was survived only by daughters and securing the succession of the eldest required drastic changes to house laws and much diplomatic activity, but still resulted in a succession war (1740-1748).

81 Karl Vocelka, Die Familien Habsburg und Habsburg-Lothringen. Politik-Kultur-Mentalität (Vienna, 2010) 20: 'Der Konflikt war vorprogrammiert.'

82 Lackner, 'Das Haus Österreich', 275 mentions that Maximilian did achieve greater unity than before also in an institutional sense, but throughout the sixteenth and early seventeenth centuries the Austrian territories usually remained divided among various Habsburg princes. 
The Iberian kingdom of Castile was much more unified, and its succession was laid down in a number of decrees and laws. ${ }^{83}$ Foremost among these were the Siete Partidas, drafted by the Castilian King Alfonso $x$ the Wise (1221-1284), which stipulated male-preference primogeniture and the indivisibility of the Castilian crown. ${ }^{84}$ Possibly inspired by Roman law, ${ }^{85}$ the law also stipulated that the rights of a deceased heir might be 'represented' by his heirs. This law was immediately disputed. Alfonso's eldest son died in 1275, leaving two toddler sons. According to the new law, Alfonso's eldest grandson now became his heir, but instead, his second (and now eldest surviving) son Sancho 'el Bravo' (12581295), who had already proved himself in battle against the Muslim princes of the Peninsula, had himself accepted as heir. ${ }^{86}$ In practice, the suitability of a pretender (a seasoned general versus a child) determined the succession more than the letter of the law. Various other successions were also challenged: Peter I 'the Cruel' (1334-1369) was murdered by his illegitimate half-brother Henry II (1334-1379, founder of the House of Trastámara) in 1369, while Henry IV (14251474) was briefly deposed in 1465 , and his only child and heiress Joanna (14621530) could not secure her succession. Instead, after a civil war, Henry's halfsister Isabella 'the Catholic' managed to claim the throne. ${ }^{87}$ Isabella's heir was again female, her daughter Joanna, and she was also excluded from ruling her lands-although not officially from the succession itself - by her father, husband, and son on grounds of insanity (she is known to historians as 'Johanna the $\left.\mathrm{Mad}^{\prime}\right) .8$

83 Horst Pietschmann, 'Reichseinheit und Erbfolge in den Spanischen Königreichen', in: Johannes Kunisch and Helmut Neuhaus, eds., Der dynastische Fürstenstaat (Berlin, 1980) 199-246.

84 Las Siete Partidas, Vol. 2. Medieval Government: The World of Kings and Warriors, Robert I. Burns, ed., trans. Samuel Parsons Scott (Philadelphia, 2001) 366-367: Partida II, Title XV, law II.

85 Alfonso had been elected Holy Roman Emperor, although the election was disputed, and thus wanted to connect Castilian history and law to the Roman Empire.

86 Las Siete Partidas, 370-373: Partida II, Title Xv, law II. Jerry R. Craddock, 'Dynasty in Dispute: Alfonso x el Sabio and the Succession to the Throne of Castile and Leon in History and Legend', Viator 17 (1986) 197-219, 199; Fernando Arias Guillén, 'El linaje maldito de Alfonso x. Conflictos en torno a la legitimidad regia en Castilla (c. 1275-139o)', Vínculos de Historia 1 (2012) 147-163, 156.

87 Luis Suárez Fernández, Nobleza y monarquía. Entendimiento y rivalidad. El proceso de construcción de la Corona española (Madrid, 2003 [1959]) 9, 301-366.

88 Bethany Aram, Juana the Mad: Sovereignty and Dynasty in Renaissance Europe (Baltimore, 2005); Salvatore Poeta, 'From Mad Queen to Martyred Saint: The Case of Juana la Loca 
There are also instances of 'legitimism', as when Fernando (1380-1416), the brother of the mortally ill Henry III (1379-1406), refused to take the throne, but instead allowed his underage nephew to take it-even though the Castilian aristocracy would have accepted his rule. ${ }^{89}$ However, at the same time, Fernando acquired the Aragonese throne over other candidates who perhaps had better rights, but were only minors at the time. ${ }^{90}$ Such adult challengers were usually successful only if they could count on the support of elites and representative assemblies, who could furnish money and military power to support supposed rights. In any case, Iberian history shows that in spite of the existence of codified succession law, minor or female heirs could not be certain that their rights would be respected by adult male kinsmen.

The Aragonese succession was (officially) less fixed than the Castilian succession. It depended greatly on the testament of the last ruler, while the position of women in the succession was limited - they could only pass their rights on to their sons and act as regents. ${ }^{91}$ However, in both crowns the influence of revived Roman law led to an emphasis on one universal heir, which in turn promoted primogeniture over partible inheritance. ${ }^{92}$ In practice, after the Aragonese and Castilian crowns had been united by the marriage of the Catholic Monarchs (1467), the Aragonese cortes would agree to uphold Castilian succession law and thus maintain the union. ${ }^{93}$ In any case, even when succession law was codified, actors had some room for manoeuvre to prefer a more desirable (male, adult) heir over a legitimate but not convenient (female, minor) heir.

From the fourteenth century onwards, the Valois dukes of Burgundy had brought an ever increasing number of principalities in the Low Countries under their control by a combination of legitimate succession, marriage, pur-

Revisited in History and Art on the Occasion of the 450th Anniversary of her Death', Hispania 9o, no. 1 (2007) 165-172.

89 Suárez Fernández, Nobleza y monarquía, 157, n. 5; Juan Torres Fontes, 'La regencia de Don Fernando de Antequera', Anuario de Estudios Medievales 1 (1964) 357-429, 378.

$90 \quad$ José Luis Martín, 'Fernando de Antequera y el Compromiso de Caspe. ¿Una incorporación a España?', Espacio, Tiempo y Forma, Serie III, Historia Medieval 13 (2000) 161-176, 168169.

91 Adela Mora Cañada, 'La sucesión al trono en la Corona de Aragón', in: Josep Serrano Daura, ed., El territori i les seves institucions historiques. Actes de les Jornades d'Estudi (Ascó, 1997) 547-566; Alfonso García-Gallo, 'El derecho de sucesión al trono en la Corona de Aragón', Anuario de Historia del Derecho Español 36 (1966) 5-187.

92 Pietschmann, 'Reichseinheit und Erbfolge', 224.

93 Pietschmann, 'Reichseinheit und Erbfolge', 230-231. 
chase, conquest, and negotiation. ${ }^{94}$ The duchy of Burgundy proper fell under French Salic law and was therefore destined for the eldest son. But other territories could be distributed more freely. Multiple heirs in the ducal house thus brought about a three-way partition in 1405 among the sons of Duke Philip the Bold (1342-1404). Throughout the fifteenth century, Duke Philip the Good of Burgundy (1396-1367) would strive to bring ever more territories under his control-including those that had been inherited by his uncles. He was helped by his family connections to most Netherlandish ruling houses, but virtually every succession was contested and other pretenders needed to be bought off. 95 In short, the various principalities of the Low Countries had been quite flexible with regard to the succession of rulers, especially when other candidates were women or minors. The arrival of the Valois rulers was not accompanied by the evolution of a joint law of succession to regulate future successions. After the acquisitions of the fourteenth and fifteenth centuries (interrupted by the partition of the early fifteenth century), cohesion was in fact mainly stimulated by a scarcity of heirs. Both John the Fearless (1371-1419) and Philip the Good had only one son, while the latter's heir Charles the Bold (1433-1477) had only one child - a daughter, Mary the Rich. She, again, only had one son (and a daughter). Apart from the matter of Mary's marriage, succession was thus quite straightforward, but for demographic reasons rather than political ones.

A joint succession law was agreed with the States General only in 1549. It was intended to unify the succession laws in the different provinces, especially regarding the right of representation, which was not accepted everywhere. This meant that if Charles v's heir Philip (1527-1598) should predecease his father, some provinces might accept Philip's son as heir, while others could prefer Philip's eldest sister. ${ }^{96}$ The Pragmatic Sanction stipulated that all seventeen Low Countries should accept the same heir by instituting the right of representation, although no mention was made of primogeniture, allowing for the succession of a younger child - as happened after the death of Philip II in 1598 but had been contemplated on many occasions. ${ }^{97}$

94 Robert Stein, De hertog en zijn staten. De eenwording van de Bourgondische Nederlanden ca. 1380 - ca. 1480 (Hilversum, 2014) 55-59.

95 Stein, De hertog en zijn staten, $30-55$.

96 The text mentions that in Flanders, Henault, Artois, and several others the right of representation was not valid. A.S. de Blécourt and N. Japikse, eds., Klein plakkaatboek van Nederland. Verzameling van ordonnantiën en plakkaten betreffende regeeringsvorm, kerk en rechtspraak (14e eeuw tot 1749) (Groningen and The Hague, 1919) vol. x, 77-79. 
By the end of the fifteenth century, existing succession laws and practices thus stressed the unified nature of (certain clusters of) the Habsburg territories: Castile-Aragon and the Low Countries. No such succession law came into existence for the Austrian territories, which continued to be partitioned among male heirs. When the two Habsburg brothers Charles and Ferdinand came to power between 1515 and $15^{20}$, they acquired a great number of territories and patrimonies, and their composite monarchy clearly transcended such clusters. No succession law for the whole of the Habsburg monarchy was ever codified, which meant that royal testaments and negotiations were instrumental in arranging the succession of (or rather, the distribution of) the entire Habsburg patrimony. This offered them the possibility of partition, which was sensible given the size of the family's holdings, the presence of several male family members, and, of course, existing traditions in Austria. Accordingly, Charles and Ferdinand were encouraged by the testaments of their grandfathers to share their patrimony - they duly worked out a division through various treaties in the 1520s. Between them, they had four legitimate sons, whom they intended to provide for around the 155 os. $^{98}$

The partition of the patrimony between Charles and Ferdinand around 1520 , and its further consolidation in the 1550s, created a lasting division within the Habsburg House. Charles held the Low Countries, Spain (with its overseas empire) and parts of Italy, while Ferdinand received Austria and anything he acquired through marriage. From this moment we can speak of a Spanish line (descended from Charles) and an Austrian line (descended from Ferdinand). In the remainder of this section, we will mainly discuss the Spanish Habsburgs. They represented the senior branch of the dynasty, and their conglomerate monarchy was the most powerful European state in the sixteenth and seventeenth centuries - engendering fears of universal rule, just as the Mongols had

(1598-1621) and Habsburg Political Culture in an Age of Religious Wars (Farnham, 2012) 6566. José Pellicer de Ossau y Tovar, La fama austriaca, o Historia panegirica de la exemplar vida, y hechos gloriosos de Ferdinando segundo (Barcelona, 1641) 132 notes that Charles V had intended to leave the Low Countries as a separate kingdom for his younger son Fernando (who died young). The Emperor later stipulated in his testament that the Low Countries would be inherited by a possible son born to Philip II of his (second) marriage to the queen of England, whereas the rest of the patrimony was to be inherited by Philip's son from his first marriage. Testamento de Carlos v, Manuel Fernández Álvarez, ed. (Madrid, 1982) 29 .

98 M.J. Rodríguez-Salgado, The Changing Face of Empire: Charles V, Philip II, and Habsburg Authority, 1551-1559 (Cambridge, 1988) 34. Charles had only one legitimate son, but Ferdinand had three, each of whom received part of his share of the monarchy. 
claimed. The Austrian branch would soon monopolize the imperial title and thus ranked higher than their Spanish cousins, but they would not obtain true 'great power' status until the eighteenth century.99

Within the Spanish branch, the opportunities on offer to continue the family tradition of partible inheritance were increasingly discarded. For one, Charles $\mathrm{V}$ had only one son, which secured dynastic unity throughout the sixteenth century. Philip II divided his inheritance between his daughter (the Low Countries) and son Philip III (the rest), mainly because he hoped this would end the revolt of the Low Countries. ${ }^{100}$ Philip III (1578-1621) had three sons, but stipulated in his testament that the inheritance should be passed whole to the eldest, which happened during the remainder of Habsburg rule in Spain. The patrimony was conceptualized in the royal testaments as a mayorazgo, which was a legal construction that created the obligation for aristocratic patrimonies to be passed on to one single heir. The two brothers of Philip IV $\left(1605^{-1665)}\right.$ were thus the first disinherited (legitimate) adult males of the dynasty.

The kings of Spain were also increasingly focused on following male primogeniture-even if the succession laws of their territories did not exclude females from the succession. ${ }^{101}$ Most of Philip Iv's thirteen legitimate children died in childhood. For a long time, it seemed that he might be survived only by a daughter. This caused the king considerable anxiety-he begged his pen pal, the nun Sor María de Jesús de Ágreda, numerous times to pray for a male successor, as if he did not have any heirs. ${ }^{102}$ We must note that such ideas were not always shared by the political elites of the country, who were happy to accept a brother or daughter as heir in the absence of a son. ${ }^{103}$ Apparently, the court of Madrid celebrated the birth of royal children with equal joy regardless of their gender, since daughters could inherit and thus represented dynastic continuity just as much as their brothers. ${ }^{104}$ On the other hand, the non-

99 Michael Hochedlinger, Austria's Wars of Emergence 1683-1797 (London, 2003).

100 Testamento de Felipe II, Manuel Fernández Álvarez, ed. (Madrid, 1982) 73-75.

101 In practically all Habsburg territories women had recently inherited the crown: Mary the Rich in the Burgundian conglomerate; Isabella the Catholic in Castile and her daughter Joanna both in Castile and the Aragonese crown. Only Milan-which was an imperial fief-did not have any experience with female rule.

102 Liesbeth Geevers, 'The Miracles of Spain: Dynastic Attitudes to the Habsburg Succession and the Spanish Succession Crisis (1580-170o)', Sixteenth Century Journal 46, no. 2 (2015) 291-311, 306-307.

103 Geevers, 'Miracles of Spain', 307.

104 The Tuscan ambassador Riccardi reported after the birth of the Infanta María Teresa in 
codified preference for male successions fit neatly in the Iberian tradition, which had seen the disinheriting of several female heiresses.

Looking back, we can detect a number of factors that influenced successions within the Habsburg dynasty and in the territories that they inherited. Most important was perhaps the number of heirs. Single heirs heralded periods of unity both in the Austrian duchies, the Low Countries, and within the Spanish branch at large, while plural heirs led to partitions and negotiations. Only in the seventeenth century were legitimate adult males excluded from any part of the inheritance. Although intra-dynastic relations were at times tense and negotiations protracted, partitions rarely led to violence-only fifteenthcentury Castile knew a real succession war and the medieval Habsburgs had occasionally come to blows.

Furthermore, we can conclude that Habsburg succession practices were greatly influenced by local constitutional agreements. This is particularly true within the 'clusters' (e.g. the Low Countries or the Iberian Peninsula). Whenever successions were contested, local estates generally tilted the balance towards one pretender or another, while they also agreed to codify succession laws. However, the power of the estates - guardians of tradition-also meant that codified law could be discarded as long as they agreed to it. We have seen examples of various Castilian usurpers who quite easily maintained their position. Furthermore, the estates might be enlisted to change codified law, as happened in the Low Countries. The existence of codified succession law therefore did not automatically determine successions. The individual attitudes of rulers also played a role. Philip Iv's example shows how this king fretted over the absence of a son. Apparently, he had little faith in a successful succession of his daughter-even if local codified law would allow her succession practically everywhere and the estates were ready to swear fealty to her.

The power of estates was not as great at the level of the entire monarchy in its sixteenth-century guise - which, as a whole, did not have a representative assembly. The discussions of the 155 os were therefore conducted with the preferences of the local elites in mind (for instance, the degree to which German princes would be willing to accept the Castilian Prince Philip as the new emperor), but without including them as partners in the talks. Over the course of the sixteenth and seventeenth centuries, a primogeniture regime would be increasingly applied to all Spanish Habsburg territories - turning the entire

1638, that 'since girls inherit, they are almost as important as boys.' Archivio di Stato di Firenze, Mediceo del Principato, Filza 4964, nr. 97: 'heredando qua le femine importan quasi l' istesso'. 
monarchy into an entail. Since no succession laws existed that covered the entire monarchy, this was essentially a matter of dynastic policy informed by concerns for the prestige of the dynasty and worries about the separate viability of its constituent parts. Succession was clearly not simply a matter of law, but equally of tradition.

\subsection{Multiple Dynastic Concepts}

In terms of succession practices, the Habsburgs transitioned towards a primogeniture regime in their entire patrimony between the sixteenth and seventeenth centuries. Successions were closely related to dynastic concepts-that is, the articulation of the dynasty's core values and characteristics, its destination and its rights to rule, as well as the representation of the dynasty as a (hierarchically ordered) group in text and image that embodies these values. Prominent examples include Castile, where - as we shall see below-usurpers could sit quite comfortably on the throne as long as they embodied the core value of Castilian kingship: Reconquista success. In this section, we will discuss several aspects of the Habsburg dynastic concept. First, we will consider how local legitimizing narratives were adopted by the Habsburgs; and second, we will analyse how the dynasty as a family group was represented in genealogies and funerary architecture.

Lineages generally need a 'story' to connect them to their possessions: a story that placed the lineage in metanarratives about world history, justified their tenure of their territories, and identified those individuals who could be considered stakeholders of the dynasty. As with succession practices, the Spanish Habsburg dynastic concept was heir to various traditions. Although these traditions usually emphasized the universal aspirations of the incumbent princethe medieval Habsburg claim of descent from Aeneas, Augustus, and Charlemagne; the imperial tradition of the Holy Roman Empire and intermittently of Castile; the Carolingian descent and Golden Fleece of the Burgundiansall these traditions functioned in a specific territorial context. This meant that along with territorial expansion, the Spanish Habsburgs had to bring their legitimizing narratives in line with various local expectations. Here we can also detect a dynamic between dynastic and territorial traditions, which led to a blending of concepts linking the Habsburgs to the Iberian Peninsula, the Low Countries, the imperial tradition, and 'universal monarchy'.

Throughout the course of their existence, the Habsburg lineage acquired many territories where they were (at first) perceived as strangers. The fact that historians sometimes present their empire-building as one long triumphant marriage feast does not do justice to the trouble they had at being accepted by their new subjects. Their connection to new patrimonies was not always 
clear and concepts linking the lineage to them needed to be elaboratedblood ties to the previous incumbent were never enough. Local elites played a significant role in the shaping of these concepts and in connecting the ruler to the land — often quite literally by forcing him to reside there, or by demanding he leave a close relative as his governor. In the Middle Ages, the elites of the newly acquired territories of Austria and Styria continued to see their rulers for several generations as 'landesfremd', until they settled more permanently in Vienna. ${ }^{105}$ After the early death of his wife Duchess Mary of Burgundy, Maximilian faced considerable opposition from towns and the estates to his attempts to secure the regency for his young son Philip in the Low Countries. ${ }^{106}$ Philip himself, born in the Low Countries, never had problems being accepted in the Netherlands. But when he had grown up and become co-ruler of Castile with his wife Joanna in 1504, he faced fierce opposition there from, among others, his own father-in-law Ferdinand of Aragon. ${ }^{107}$ Philip's early death in 1506 and Joanna's declared insanity meant that their son Charles became their heir. But Charles's transition from a Burgundian prince-he was born in Ghent and raised in Malines ${ }^{108}$ — to a Spanish ruler was by no means easy either. His arrival in Spain in 1517 (after the death of Ferdinand of Aragon), accompanied by a large Burgundian retinue, which soon laid claim to all major political and religious positions, aroused serious opposition. In $15^{20}$ and $15^{21}$ Charles faced widespread revolts in Castile and Valencia. ${ }^{109}$ After he had established peace and had reorganized his administration, the Cortes-representing eighteen Castilian towns-more or less forced the new ruler to contract an Iberian marriage and to thoroughly Hispanicize his court. ${ }^{110}$

\footnotetext{
105 Lackner, 'Das Haus Österreich', 276.

106 Jelle Haemers, 'Factionalism and State Power in the Flemish Revolt (1482-1492)', Journal of Social History 42, no. 4 (2009) 1009-1039.

107 Raymond Fagel, 'De Spaanse zomerkoning. Filips de Schone als koning van Castilië', in: Raymond Fagel, Jac Geurts and Michael Limberger, eds., Filips de Schone, een vergeten vorst (1478-1506) (Maastricht, 2008) 101-136, 105-111.

108 Wim Blockmans, Karel V (Utrecht, 2012).

109 John H. Elliott, Imperial Spain 1469-1716 (London, 1963) 130-163.

110 José Luis Gonzalo Sánchez-Molero, 'Felipe II, princeps hispaniarum: la castellanización de un príncipe Habsburgo (1527-1547)', Manuscrits 16 (1998) 65-85, 71. The prospective bride, Isabella of Portugal, was half-Spanish on her mother's side (she was a granddaughter of the Catholic Monarchs), which made her 'muy amiga' to the Spanish nation. Aurelio Espinosa, 'The Formation of Habsburg Rule in Spain, 1517-1528', (PhD dissertation, University of Arizona, 2003) 267-277.
} 
Although Charles never settled in Castile permanently as this would have countered the wishes of his other subjects, ${ }^{111}$ he did manage to adapt to the Castilians; he learned Castilian, and after the death of a number of early favourites - such as the Burgundians William of Croÿ-Chièvres (1521) and Henry of Nassau (1538), the Savoyard Mercurino di Gattinara (1530), and Charles's aunt and governess Margaret of Austria (1530) - he became less 'Burgundian', spending ever more time outside of his natal lands and relying more and more on Castilian advisors. ${ }^{112}$ Charles's son and heir Philip was consequently born in Castile (Valladolid, 1527) and was therefore considered a 'natural prince' in Spain. ${ }^{113}$ The young prince underwent a conscious and strategic process of 'castilianisation',114 and his household was modelled after that of his greatuncle Prince Juan, the last Spanish-born crown prince, as the representatives of the Cortes had insisted. ${ }^{115}$ However, although the future Philip II of Spain was seen by his subjects in Spain as their natural prince and he would develop into a Castilian monarch, this would make it more difficult for non-Iberian subjects to identify with him. In 1548 , he would travel extensively through

111 René Vermeir, 'How Spanish Were the Spanish Netherlands?', Dutch Crossing 36, no. 1 (2012) 3-18, 6: 'A calculation based upon the emperor's itinerarium, published by Vicente de Cadenas y Vicent, reveals that between his election and his abdication, he devoted $29 \%$ of his time to Castile and 9.9\% to Aragon, and $26.3 \%$ to the Low Countries, $23.7 \%$ to the Holy Roman Empire, and $2.1 \%$ to his Italian possessions. The emperor spent around $9 \%$ of his time-during his travels and battles—on foreign soil.'

112 The turning point is often situated around 1530. See for instance, Wim Blockmans and Walter Prevenier, The Promised Lands: The Low Countries under Burgundian Rule, 13691530 (Philadelphia, 1999) xii, 233, and also José Martínez Millán, 'Evolución de la Monarquía hispana: de la Monarchia universalis a la 'Monarquía católica' (siglos xvi-xvii)', in: Leonardo Funes, ed., Hispanismos del mundo: diálogos y debates en ( $y$ desde) el Sur (Buenos Aires, 2016) 107-130, 109.

113 Gonzalo, 'Felipe II, princeps hispaniarum', 73-75.

114 This process appeared to have suffered a blow at the prince's baptism, when the Duke of Alba audibly lobbied for him to be named 'Fernando', but the child was baptized 'Philip' for his Burgundian grandfather. Gonzalo, 'Felipe II, princeps hispaniarum', 65-85; see also his El aprendizaje cortesano de Felipe II, 1527-1546: La formación de un príncipe del Renacimiento (Madrid, 1999), and 'El príncipe Juan de Trastámara, un "exemplum vitae" para Felipe II en su infancia y juventud', Hispania. Revista española de historia 59, no. 203 (1999) 871-896.

115 Gonzalo, 'Felipe II, princeps hispaniarum', 8o. In 1548, when Philip was already twenty-one years old, Gonzalo Fernández de Córdoba, an old courtier of Prince Juan, was ordered to put his memories of the prince's household to paper: Gonzalo Fernández de Córdoba, Libro de la cámara real del príncipe don Juan, J.M. Escudero de la Peña, ed. (Madrid, 1870) and Santiago Fábregat Barrios, ed. (Valencia, 2006). 
Europe-passing through Italy, Germany, and the Low Countries-in order to get acquainted with his future subjects and to facilitate his succession. ${ }^{116}$ Part of this new acquaintance between the prince and his subjects was the introduction of yet another court organization. This time, Burgundian court ceremonial was revived to create a more recognizable entourage for Philip's Netherlandish subjects. ${ }^{117}$ However, Philip decided to settle in Castile more or less permanently in 1559; in 1561 he fixed the capital in Madrid. ${ }^{118}$

Subjects clearly wanted their rulers to be 'natural princes' - that is, born locally—or at least sensitive to local court traditions. Since this was practically impossible to achieve in a wide-spread conglomerate like the Spanish Habsburg Monarchy, the Spanish Habsburgs developed an ideology that blended legacies connected to the Iberian Reconquista past and the Burgundian Golden Fleece, and was also connected to the idea of a world empire. In this way, a legitimizing narrative took shape that was connected to all the major clusters of the Habsburg monarchy. The Reconquista past had a strong resonance on the Iberian Peninsula. Richard Kagan argued that the Spanish view of history was based on two pillars; the first was a 'nostalgic vision of Hispania- united, prosperous, and above all, Christian - that awaited recovery and restoration through heroic royal action.' The second was 'a record of Gothic accomplishments and success that rested, as Isidore had written, more on "force rather than prayers".'119 These strands combined to teach Castilian kings (and their subjects) that the legitimacy of their rule was determined by their success in restoring the Visigothic kingdom that had been lost to Muslim invaders in $711 \mathrm{CE}$. At the end of the fifteenth century, the conquest of Granada - the last Muslim principality on the Iberian Peninsula-marked the successful conclusion of the Reconquista and gave a giant boost to the legitimacy of the Catholic Monarchs and their successors - who could with some justification be said to have stolen the throne from Henry Iv's daughter Joanna. ${ }^{120}$ The success of such

116 The trip is known as the 'felicísimo viaje'—the most fortunate journey—and was meticulously documented by the Spanish courtier Juan Cristóbal Calvete de Estrella in his El felicísimo viaje del muy alto y muy poderoso príncipe Don Felipe (Antwerp, 1552).

117 Helen Nader, 'Habsburg Ceremony in Spain: The Reality of the Myth', Historical Reflections/Réflexions Historiques 15, no. 1 (1988) 293-309, 294, cites Calvete de Estrella, El felicísimo viaje, Miguel Artigas, ed. (Madrid, 1930) 4.

118 Alfredo Alvar Ezquerra, Felipe II, la corte y Madrid en 1561 (Madrid, 1985) 3-9, 31-34.

119 Richard Kagan, Clio and the Crown. The Politics of History in Medieval and Early Modern Spain (Baltimore, 2009) 20.

120 Andrew Devereux, 'The Other Side of Empire: The Mediterranean and the Origins of a Spanish Imperial Ideology, 1479-1516', (PhD dissertation, Johns Hopkins University, 2011). 
'usurpers' as Sancho IV (another Reconquista-hero who took the throne from his nephew) and Isabella the Catholic in consolidating their rule shows that living up to the Reconquista ideal could really make or break a Castilian king. ${ }^{121}$

The most important non-Iberian legacy was the Burgundian one-represented by the title 'Duke of Burgundy' which the Habsburgs continued to use long after the loss of the duchy — of which the most important element was the Order of the Golden Fleece. The Order of the Golden Fleece had been established by the Burgundian Duke Philip the Good in 1430, on the occasion of his marriage to Isabella of Portugal. And although he was a 'mere' duke, in his foreign policy, courtly splendour, and wealth he could match the monarchs of his day. ${ }^{122}$ The foundation of this order of chivalry was intended to emulate the English Order of the Garter. The order was also founded in an atmosphere of eschatological expectation: the Ottomans were closing in on Constantinople, and various European monarchs stated their desire to renew the Crusades. In 1473, the Order's chancellor Guillaume de Fillastre delivered a number of sermons to the Order's chapter-later developed into books - in which he elaborated the Greek myth of Jason (who had been tasked to retrieve a golden fleece of a ram that was guarded by a dragon) as an analogy of the redemption of mankind. Jason's quest to retrieve the fleece was equated with mankind's quest to gain redemption; the fleece itself represented Christ's human body, while Jason represented Christ the Saviour. ${ }^{123}$ As sovereigns of the Order, the Burgundian dukes and their Habsburg successors presented themselves therefore as the ultimate miles christi, as successors of Jason/Christ-which of course dovetailed nicely with the Iberian wish for a crusader king.

After the death of the last Duke of Burgundy, Maximilian of Austria happily took over the role as (acting) sovereign of the Order. He organized a chapter in 1478, only months after his marriage to the heiress Mary of Burgundy and his arrival in the Low Countries. The importance of the order in the establishment of a new ruler was also demonstrated twice by Charles v, who orga-

121 See also T.F. Ruiz, From Heaven to Earth: The Reordering of Castilian Society, 1150-1350 (Princeton, 2004) 134-135. Another example is Ferdinand III of Castile (r. 1230-1252), who also took the throne of León even though his older half-sister (from his father's first marriage) had been designated the heir. He made up for this usurpation by conquering Córdoba and Seville, which led to his beatification in 1671 .

122 Blockmans and Prevenier, Promised Lands, 133-134.

123 Marie Tanner, The Last Descendant of Aeneas: The Hapsburgs and the Mythic Image of the Emperor (New Haven, 1993) 57-58; Barbara Haggh, 'The Mystic Lamb and the Golden Fleece: Impressions of the Ghent Altarpiece on Burgundian Music and Culture', Revue belge de musicologie 61 (2007) 5-59, 31. 
nized a chapter in Brussels in 1516, soon after obtaining his majority and just before leaving for Castile to take the throne there; and again, after his arrival in Spain, in Barcelona (1519). Philip II did the same after his accession in 1555 and before he left the Low Countries, in 1559. At the same time, membership of the order could be easily broadened to accommodate new Castilian, Aragonese, and Italian elites and thus became one of the unifying elements in the far-flung and diverse Habsburg Monarchy. ${ }^{124}$ By the mid-sixteenth century, Netherlandish aristocratic lineages like the Croÿ and the Nassau had become practically hereditary members of the Order, while the same went for the Castilian houses of Alva and Feria, and the Italian houses of Farnese, Doria, and Aragona.

The Golden Fleece and the Reconquista legacies were joined by the eschatological 'fourth empire' legacy, traditionally associated with the Roman Empire and later with its perceived successor, the Holy Roman Empire. The Roman Empire was the fourth of the 'four world empires' prophesized by Daniel and preceded by the Babylonian, Medo-Persian, and Greek empires. ${ }^{125}$ This provided the Empire with a sacred purpose. As the last empire on earth before the return of Christ, it was meant to unite the world under its rule. This sacred purpose was transferred to all empires that claimed to be continuations of the Roman Empire. ${ }^{126}$

The ancient Roman emperors were connected to their fifteenth-century successors in the Holy Roman Empire via the person of Charlemagne. Charlemagne, who restored the empire in Europe when he was crowned emperor in $800 \mathrm{CE}$, was claimed to be a descendant of Julius Caesar, while practically all ruling houses claimed him as their ancestor. Thus, authors of chronicles and genealogies forged genealogical ties between ancient Rome and contemporary polities. The Renaissance further stimulated the 'awakening' of the imperial tradition, causing many princes to envisage themselves as new Juliuses and Augustuses. ${ }^{127}$ Maximilian was instrumental in co-opting this trend for the Habsburgs. His French contemporaries Charles VIII (r. 1483-1498) and Louis XII

124 H. Kervyn de Lettenhove, La Toison d'Or: notes sur l'institution et l'histoire de l'Ordre (depuis l'année 1429 jusqu'à l'année 1559) (Brussels, 1907); F.A.F.Th. baron de Reiffenberg, Histoire de l'ordre de la Toison d'or depuis son institution jusqu'à la cessation des chapitres généraux (Brussels, 1830).

125 Tanner, Last Descendant, 24.

126 In Western Europe, this was primarily the Holy Roman Empire of the German Nation; outside Western Europe the Byzantines and in their wake the Ottomans and Russians claimed this status.

127 Thomas J. Dandelet, The Renaissance of Empire in Early Modern Europe (Cambridge, 2014); Frances A. Yates, Astraea: The Imperial Theme in the Sixteenth Century (London, 1975). 
(r. 1498-1515) were presented by their own chroniclers, poets, and painters as the heirs of Charlemagne and Augustus, and therefore as world emperors. ${ }^{128}$ These French claims fuelled Maximilian's efforts to prove his own status as true leader of the Christian world. This competition was dangerous, because although Maximilian had been elected King of the Romans, ${ }^{129}$ he would never actually be crowned Emperor and thus had to resort to other means to claim imperial status. ${ }^{130}$ As a result, Maximilian made a huge effort to boost the prestige of his dynasty and the imperial office as the foremost dignity of Europe.

Charles v, Maximilian's grandson, was the beneficiary of Maximilian's efforts, and his exalted ancestry, in combination with his huge inheritance (joining Aragon, Castile, the Americas, Naples, and Sicily with the Low Countries and the Austrian archduchies) - along with, of course, suitable bribes, landed him the imperial election. ${ }^{131}$ Amid the 'twin eschatological signs provided by the discovery of America and the Antichristic presence of the Turk, ${ }^{132}$ Charles was the object of great propagandistic efforts connecting him to the Roman emperors and universal monarchy ${ }^{133}$ and at the same time presenting him

128 R.W. Scheller, 'Imperial Themes in Art and Literature of the Early French Renaissance: The Period of Charles virI', Simiolus 12 (1981-1982) 5-69; and idem, 'Ensigns of Authority: French Royal Symbolism in the Age of Louis XII', Simiolus 13 (1982) 75-141; idem, 'Gallia Cisalpina: Louis XII and Italy 1499-1508', Simiolus 15 (1985) 5-5o. For later periods, see Alexandre Y. Haran, Le lys et le globe: Messianisme dynastique et rêve impérial en France aux XVIe et XVIIe siècles (Seyssel, 200o) and Michael Rohrscheider, 'Das französische Präzedenzstreben im Zeitalter Ludwigs XIV. Diplomatische Praxis—zeitgenössische französische Publizistik—Rezeption in der frühen deutschen Zeremonialwissenschaft', Francia ${ }_{3} 6$ (2009) 135-179.

129 The King of the Romans was the elected chief of the Holy Roman Empire before his imperial coronation, after which he was emperor. During the later sixteenth and seventeenth centuries, 'King of the Romans' would come to indicate the elected successor of the reigning emperor or his lieutenant (in the case of Charles v's brother Ferdinand). Maximilian I had been elected King of the Romans (successor to his father Emperor Frederick III) in 1486, but had since his father's death not been crowned. He was therefore in a way still King of the Romans. In 1508, he would assume the title 'Elected Emperor.'

130 Larry Silver, Marketing Maximilian: The Visual Ideology of a Holy Roman Emperor (Princeton, 2008).

131 Rebecca Ard Boone, Mercurino Di Gattinara and the Creation of the Spanish Empire (London, 2014) 16.

132 John M. Headley, Tommaso Campanella and the Transformation of the World (Princeton, 1997) 199.

133 Boone, Mercurino Di Gattinara; John M. Headley, The Emperor and his Chancellor: A Study of the Imperial Chancellery under Gattinara (New York, 1983). 
as the ultimate miles christi. ${ }^{134}$ After Charles's abdication the imperial throne passed to his brother Ferdinand. But his son Philip—a mere king of Castilestill claimed the imperial tradition because of his descent from Charles v, the impressive expansion of the Spanish Habsburg Empire in the Americas, Asia, and Europe, and the acquisition of Portugal and its dependencies in 1580-1583. Although the French king would continue to dispute Spain's imperial aspirations, ${ }^{135}$ many contemporary commentators considered Spain, rather than the Holy Roman Empire, the new 'world empire'-among them, for instance, Tommaso Campanella, who described in The Monarchy of Spain how the Spanish king could obtain universal monarchy. ${ }^{136}$ The Roman Legacy was now reincarnated in a kind of super-kingdom of Spain, instead of in the Holy Roman Empire. ${ }^{137}$

The blending of different legacies was made visible in the king of Spain's titles, starting particularly with Philip II. Whereas Charles v was known mostly by his most exalted title of Emperor-hence Charles v and not Charles I as he was in Castile-his heirs would be known as the king of Spain, or Rex Hispaniarum. This was a fictional title, since 'Spain' or the 'Spains' did not exist as a kingdom, but only as a geographical term (rather like Scandinavia). Philip II was well aware of this, and he notably omitted the title from his testament. ${ }^{138}$ The title Rex Hispaniarum had been used before by the Castilian king Alfonso $\mathrm{x}$,

134 The best-known artworks that put forward this message are Titian's Emperor Charles $V$ at the battle Mülberg (commissioned by his sister Mary of Hungary) and Leone Leoni's Emperor Charles $v$ as Virtue subduing Fury, which he himself commissioned. Jennifer Liston, 'The Performance of Empire: Leone Leoni's Charles v as Virtus Subduing Fury', Visual Resources: An International Journal of Documentation 28, no. 1 (2012) 24-42.

135 See Liesbeth Geevers, 'The Conquistador and the Phoenix. The Franco-Spanish Precedence dispute (1564-1610) as a Battle of Kingship', International History Review 35 (2013) 23-41; Cornel Zwierlein, 'Normativität und Empirie. Denkrahmen der Präzedenz zwischen Königen auf dem Basler Konzil, am päpstlichen Hof (1564) und in der entstehenden Politikwissenschaft (bis 1648)', Historisches Jahrbuch 125 (2005) 101-132.

136 Headley, Tommaso Campanella, 199-201.

137 Nevertheless, the Austrian emperors also cultivated the imperial legacy. See Thomas DaCosta Kaufmann, Variations on the Imperial Theme in the Age of Maximilian II and Rudolf II (New York, 1978); Maria Goloubeva, The Glorification of Emperor Leopold I in Image, Spectacle and Text (Mainz, 200o).

138 Testamento de Felipe II, 1. His titles listed are: 'Rey de Castilla, de León, de Aragón, de las dos Sicilias, de Hierusalem, de Portugal, de Navarra, de Granada, de Toledo, de Valencia, de Galicia, de Mallorca, de Sevilla, de Cerdeña, de Córdova, de Córçega, de Murcia, de Jaén, de los Algarves, de Algeciras, de Gibraltar, de las Islas de Canaria, de las Indias Orientales y Ocidentales, islas y Tierra Firma del Mar Océano, Archduque de Austria, Duque 
who had had imperial aspirations and had been elected King of the Romans by a minority of the electoral body in 1257. In the context of Philip's reign it obviously referred to his joint Iberian kingdoms, but it also served to provide the Habsburg ruler with a title that evoked something more than the sum of his territories. 'Spain' would become the pars pro toto of all Philip's possessions. The 'Monarquía hispana' therefore had universal connotations, and the Rex Hispaniarum at its head could aspire to be lord of the world. The influence of the various local contexts in which the Habsburgs forged their dynastic concept led to a transnational dynastic 'brand' - the Habsburgs as rulers of the world. Through different aspects of this global myth - the Burgundian Golden Fleece, the Iberian Reconquista-king, the German imperial myth - the dynasty could claim to be the rightful rulers of all their territories.

In many of the territories that the Habsburgs acquired in the fifteenth and sixteenth centuries, they were at first considered to be 'foreigners', which led to resistance everywhere. As noted above, kinship and blood ties alone were nowhere near enough to persuade local elites that the new arrivals were their natural princes. Residence and marriages in line with certain local interests could put such unease to rest, but it was, of course, impossible for rulers to reside in all their territories simultaneously. Some kind of universal legitimizing narrative was therefore necessary. On a conceptual level, the traditional legitimizing narratives first developed by the Habsburgs' predecessors in the Low Countries, Iberian kingdoms, and the Holy Roman Empire had many things in common, such as a focus on Julian descent and a missionary zeal to lead the Catholic world. These narratives could be combined into a narrative about 'Spain' as a universal monarchy—which built on Iberian thoughts about Reconquista, continued the imperial tradition in a 'royal' guise, and adopted the Golden Fleece as its visual motto. The acquisition of an empire that spanned all the known continents, thus led to the elaboration of a suitably universal dynastic concept.

\subsubsection{Genealogies and the Escorial}

The genealogical aspects of the Habsburg dynastic myth were, of course, elaborated in genealogies. These sources also give us an impression of how the ruling family was depicted as a group. The Spanish genealogies generally refer to the lineage as the 'Casa de Austria', the Domus Austriae. Many genealogies reflect

de Borgoña, de Bravante, y Milán, Conde de Habsbourg, de Flandes, de Tirol y de Barcelona, Señor de Vizcaya y de Molina.' 
the mythical Trojan origins of the dynasty and trace a common origin from mythical or biblical figures such as Adam or Hector, which invariably lead to the French king Clovis, and then, descending in the male line from Merovech, on to the medieval count Ottobert/Othoperto, who was the first to be styled count of Habsburg. Then the line is traced to Emperor Maximilian I, after whom the two lines of Charles $\mathrm{v}$ and his brother Ferdinand I are discussed. ${ }^{139}$

But over time, differences emerged in the way more contemporary Habsburgs were discussed. When we analyse genealogies from the sixteenth and seventeenth centuries, we observe some notable differences. For instance, the Milanese friar Paolo Morigi, writing in 1592, presented a decidedly hotchpotch version of the Habsburg dynasty, barely distinguishing between the two lines. He dedicated his work to Empress Maria (1528-1603). As a daughter of Charles v, sister of Philip II, spouse of the Austrian Habsburg Emperor Maximilian II (1527-1576), and mother of numerous Austrian Habsburgs, she virtually embodied the connection between the two branches, which is perhaps why Morigi felt he did not need to present a strictly patrilineal account of the dynasty. Furthermore, Morigi intended to present the history of the House of Habsburg and laud the Catholicism of its members. ${ }^{140}$ Although such religious narratives were obviously connected to the Habsburgs' legitimacy as rulers, his primary focus was not on the succession to the thrones of Spain or the Holy Roman Empire. Rather, he expressly wished to include the family's pious women, whether they had married or not, extoll their virtue, and thus legitimize the position of the entire dynasty at the apex of the European Catholic society.

In line with his focus on piety and women, he pays a lot of attention to the daughters of Ferdinand I in his discussion of the descendants of Maximilian I. The piety of the Habsburg daughters is elaborately extolled, and Morigi even devotes two small chapters to the house of Bavaria (into which Ferdinand's daughter Anna married) and Lorraine (into which Anna's son William married). Since piety takes pride of place, instead of, for instance, succession, no specific order can be found in the description of sixteenth-century Habsburgs. Morigi jumps from Charles v, his youngest daughter Joanna (15351573), and illegitimate children, to his brother Ferdinand, Ferdinand's married daughters and then the houses of Bavaria and Lorraine, back to Ferdinand's daughters who became nuns; then he discusses Ferdinand's sons, including

139 Paolo Morigi, Historia brieve dell'augustissima casa d'Austria (Bergamo, 1593) jumps from Clovis straight to Maximilian and then discusses members of both lines.

140 Morigi, Historia brieve, dedication, no pagination. 
Emperor Maximilian II, his wife Maria, and two of their daughters, their son Emperor Rudolf II (1552-1612) and then finally Charles v's son Philip II. Even if we account for his focus on piety rather than succession, it is still quite striking that Morigi did not try to present the two branches as separated sharply or ordered hierarchically.

A rather different approach was taken by Lázaro Díaz del Valle y de la Puerta, whose work Mapa de la muy alta católica y esclarecida sangre austriaca y genealogia de su Magestad católica y del cesareo Emperador Ferdinando III por la Augustísima cassa de Austria was finished in $1653 .{ }^{141}$ Starting with Adam, he presents a direct line running from him to the seventeenth-century Habsburg rulers of Spain and the Empire. Each lineal ancestor is placed in a circle with a short biography, leaving aside other descendants, while each generation is numbered. After generation 119 (Philip the Fair), the genealogy splits into two lines, one descended from Charles and the other from Ferdinand (both gen. 120). From then on, the pages in the manuscript are split horizontally: the upper half is dedicated to the Spanish line, while the lower half discusses the Austrians. Generation 121 is represented by Philip II (Charles v's eldest son) and Charles of Styria (1540-1590), who was Ferdinand's third son, but was the only one to produce legitimate heirs. In generation 123 we find Philip IV and Ferdinand III (1608-1657), while generation 124, which should present their successors, is given as empty and merely expresses the hope of succession..$^{142}$ The text mentions that Ferdinand III had married the infanta Maria of Spain (1606-1646) and had two sons ${ }^{143}$ and a daughter, who was 'now' queen of Spain. On the one hand, Díaz del Valle presents the two branches as strictly separated - much more so than Morigi—but, on the other, he seems to present a sort of unification of the branches around 1650. ${ }^{144}$

141 Lázaro Díaz del Valle y de la Puerta, Mapa de la muy alta católica y esclarecida sangre austriaca y genealogia de su Magestad católica y del cesareo Emperador Ferdinando III por la Augustísima cassa de Austria desde el santo patriarca Adam por linea de varones (Manuscript 1653; Biblioteca Nacional de España Mss/1073). The author (ca. 16o6-1669) had been a courtier, serving in the royal chapel since the early 1620 , and was known from ca. 1655 as a royal chronicler as well. He is best known as Spain's Giorgio Vasari because of his collection of biographies of artists, Origen y yllustración del nobilissimo y real arte de la pintura y dibuxo (1656). See for biographical details: José María Riello Velasco, 'Lázaro Díaz del Valle y de la Puerta. Datos documentales para su biografía', De Arte. Revista de Historia del Arte 3 (2004) 105-132.

142 Díaz del Valle, Mapa, $5^{2}$ : a later hand had added the birth of Felipe Próspero, a short-lived son of Philip IV who was born in 1657 .

143 Díaz del Valle, Mapa, $5^{\mathrm{O}^{\mathrm{r}}}$ : a later hand added that the eldest of these sons had since died.

144 José Pellicer de Ossau y Tovar, La fama austriaca, o Historia panegirica de la exemplar 
In the sixteenth and seventeenth centuries, the representation of the Spanish Habsburg branch also took shape in the Escorial, which served as their burial place. When we trace the history of the dynasty's representation in the funerary architecture of the Escorial, we come across a similar development that we saw in the genealogies - from inclusive to exclusive. The Escorial, built between 1563 and 1584 , was intended to serve as a burial place for Philip II, his father, and their relatives. ${ }^{145} \mathrm{At}$ first, the king constructed a quite modest crypt below the basilica's choir, twinned by cenotaphs above ground, also in the choir area. Although the Escorial and its basilica were built on a monumental scale, the crypt was small-as was common for royal burial sites of the sixteenth century. ${ }^{146}$ This small vault was situated directly below the main altar, since Charles v had stated in his testament that he wanted to be buried 'under the feet of the priest. ${ }^{\prime 147}$ A number of Philip II's relatives were (re)buried there- they included his parents, two aunts, three wives, three brothers, five children, and a nephew. The group was arranged hierarchically around the coffin of Charles v, who was flanked on his left by his wife and sisters, and on his right a place was reserved for his son. ${ }^{148}$ Charles was thus the central individual in the vault, and Philip was positioned as his heir.

The coffins in the crypt remained out of view, but they were matched above ground by two groups of statues depicting the buried royals - minus the children - at prayer. ${ }^{149}$ Charles was depicted with his wife, two sisters, and daugh-

vida, y hechos gloriosos de Ferdinando segundo (Barcelona, 1641) gives a written genealogy that much resembles Lázaro Días del Valle's work in that it presents the two branches as distinct lineages. The work was apparently intended to show that the Habsburgs were also patrilineal descendants of Merovech and as such in line for the French throne should the Bourbons fail to produce male heirs.

145 Juan Martínez Cuesta, Guide to the Monastery of San Lorenzo el Escorial, also called El Escorial (Madrid, 1992) 12; Henry Kamen, The Escorial: Art and Power in the Renaissance (New Haven, 2010) 67-69; Juan Rafael de la Cuadra Blanco, 'La idea original de los enterramientos reales en El Escorial', Boletín de la Real Academia de Bellas Artes de San Fernando 85 (1997) 375-413.

146 Thomas Lersch, Die Grabkapelle der Valois in Saint Denis (Munich, 1995); Brigitta Lauro, Die Grabstätten der Habsburger. Kunstdenkmäler einer europäischen Dynastie (Vienna, 2007) 131-138; María José Redondo Cantera, 'Los sepulcros de la Capilla Real de Granada', in: Miguel Angel Zalama Rodríguez, ed., Juana I en Tordesillas: su mundo, su entorno (Valladolid, 2010) 185-214.

147 Testamento de Carlos V, 101 (codicil of 9 September 1558).

148 Fray José de Sigüenza, Historia primitiva y exacta del monasterio del Escorial, Miguel Sánchez y Pinillos, ed. (Madrid, 1881) 114-116.

149 De la Cuadra Blanco, 'La idea original', 375, 397. 
ter Maria (who died in 1603 and was thus still alive when the statues were commissioned but chose to be buried elsewhere); Philip with three of his four wives, and his adult son Carlos (1545-1568). The cenotaphs represent two family units focused on rulers-much like the contemporary monument to Francis I (1494-1547) at St. Denis. ${ }^{150}$ The two groups of statues took up most of the spaces around the altar, leaving no room for future additions.

Philip's son and grandson altered these arrangements. Around the altar, nothing changed, but below ground they started housing the royal coffins in a far grander vault, called the Panteón de Reyes. Here, the rulers of Spain and their wives - particularly those who were mothers of kings-were buried while all other relatives were moved to the less grand Panteón de Infantes. Whereas the older crypt had been inaccessible, the new pantheon was larger, grander, and seemingly more accessible to a (slightly) wider public; we have a number of travel journals describing the Panteones, mostly from foreign diplomats. ${ }^{151}$ The new set-up, with greater visibility of the deceased kings, was undoubtedly seen as necessary since there was no space around the altar to depict the generations of rulers that succeeded Philip II. In the new Panteón de Reyes the deceased kings of Spain were placed on top of each other, with Charles V at the top and Philip II and Philip III below him (Philip IV would later be interred in the coffin below his father's), almost like a genealogical tree. Rather than in family groups - as in the statue groups around the altarthe kings were represented as a sequence of rulers, mimicking the changes between the genealogies of Morigi and Díaz del Valle.

Apart from connecting itself to its territories - each of them separately and the whole- the Habsburgs developed concepts aimed at connecting members of the lineage to each other. The family tree stretching back to the medieval Austrian Habsburgs looked like an hour glass: the tree was wide with many branches throughout the fourteenth and fifteenth centuries, then contracted to only one person, Maximilian (and his only son Philip the Fair), and then widened again in the two main branches engendered by his grandsons Charles and Ferdinand. The early modern Habsburgs were most often portrayed as the descendants of the two brothers in joint genealogies. As the tree grew

150 The Valois monument of Francis I also depicts the king and queen and some of their deceased adult children.

151 A Dutch ambassador reported a visit to the Escorial during their mission in 1661. Van Amerongen to Willem Frederik van Nassau, Madrid 20 January 1661, Koninklijk Huisarchief, SA VII C170, cited in: Maurits Ebben, ed., Lodewijck Huygens' Spaans journaal. Reis naar het hof van de koning van Spanje, 1660-1661 (Zutphen, 2005) 279-281, n. 44. Some years later, the Duke of Saint Simon visited as well. De la Cuadra Blanco, 'La idea original', 393. 
larger during the sixteenth and seventeenth centuries, we can also detect a stronger focus on the patrilineage - apparently, the whole group of Habsburgs could be dealt with in the sixteenth century, but this had become perhaps too complicated in the seventeenth century. Possibly in connection to succession practices that reverted to the primogeniture type, the Spanish branch was increasingly thought of as a sequence of kings, rather than an extended family.

\subsection{The Social Reality of the 'Casa De Austria'}

Clearly, in the development of Habsburg dynastic concepts, the existence of the two branches played a pivotal role. This reflected the perceived unity within the one 'House of Austria', the 'Gesamthaus.'152 The Gesamthaus thesis originates in the Habsburgs' own concept of the 'Domus Austriae'. Until the fourteenth century, the Habsburg patrimony had often been referred to as the 'Herrschaft zu Österreich', or dominion of Austria. This concept implied unified rule of the house over their domains. But the fourteenth century saw a number of partitions, which fragmented rule and rendered this concept problematic. As a counterbalance, the dynasty developed a concept of the 'Domus', or House. ${ }^{153}$ This concept gave an 'ideal manifestation of the union of the ruling haus' amid administrative fragmentation. ${ }^{154}$ The 'Domus Austriae' concept gained wider use during the reign of Emperor Frederick III (14151493) $)^{155}$ who considered himself to be the head of the entire house, including a branch represented by his cousin. According to this ideal, the House need not be unified or represented by a single individual in order to still be able to direct all the Habsburgs' energies towards a common dynastic goal. By developing this concept and strategy, the Habsburg dynasty could hope to avoid the wars and conflicts between the branches that characterized the interactions among other multi-branched German dynasties. ${ }^{156}$ The family tradition would therefore advocate the continued use of partible inheritance

\footnotetext{
$15^{2}$ Heinz-Dieter Heimann, Die Habsburger. Dynastie und Kaiserreiche (Vienna, 2004) 62.

153 Lackner, 'Das Haus Österreich', 286.

154 Lackner, 'Das Haus Österreich', 287.

155 Lackner, 'Das Haus Österreich', 287. Although it remained unclear whether the concept covered the ruling house, or also the territories it ruled.

${ }_{15} 6$ See, for instance, works on the early modern Wittelsbach: Franz Fuchs, 'Das "Haus Bayern" im 15. Jahrhundert. Formen und Strategien einer dynastischen "Integration”, in: Werner Maleczek, ed., Fragen der politischen Integration im mittelalterlichen Europa (Ostfildern, 2005) 303-324 and Andrew L. Thomas, A House Divided. Wittelsbach Confessional Court Cultures in the Holy Roman Empire, c. 1550-1650 (Leiden, 2010). Paula Sutter Fichtner, Protestantism and Primogeniture in Early Modern Germany (New Haven, 1989) for many examples of conflicts among the branches of German dynasties.
} 
to provide for all its male members, while maintaining a sense of cultural unity, shared purpose, and solidarity through its 'Domus' ideology. 157

How the 'Domus' ideology translated to social reality in the early modern period is a matter of debate. Some historians have argued that a silent agreement between the two branches stipulated that the eldest Spanish princess would always marry the future emperor. ${ }^{158}$ Others also suspect that an agreement was in place, stipulating that one branch should succeed if the other became extinct. ${ }^{159}$ The two strategies would reinforce each other, since by frequent marriage between the senior male Austrian and the senior female Spaniard, the Austrians would always be the closest heirs in absence of Spanish male heirs. These arguments have often been made in the context of the War of the Spanish Succession and are probably intended to explain why the Austrians felt they were entitled to the Spanish inheritance even though the French House of Bourbon was more closely related. However, when we take a look at both marriage policies and succession arrangements throughout the sixteenth and seventeenth centuries, we can see that such assertions are not supported by the evidence.

The notion that all the eldest daughters of the Spanish king married (future) emperors proves to be false. Charles v's eldest daughter did, but no others. Philip II intended for his eldest daughter to marry the emperor-Philip's nephew Rudolf II-but the emperor did not intend to marry at all. This left her unmarried quite some time until she married a Habsburg who was unlikely to become emperor. Philip III and Philip IV married their second daughters to the emperor but their eldest to the French king-giving the latter ultimately a better claim to the Spanish patrimony. Therefore, inter-dynastic ties weregenealogically, at least—equally tight with the Bourbons in the seventeenth century.

157 Gustav Turba, Geschichte des Thronfolgerechtes in allen habsburgische Ländern bis zur pragmatischen Sanktion Kaiser Karls VI. 1156 bis 1732 (Vienna and Leipzig, 1903); on partible inheritance, see Sutter Fichtner, Protestantism and Primogeniture; J.P. Cooper, 'Patterns of Inheritance and Settlement by Great Landowners from the Fifteenth to the Eighteenth Centuries', in: Jack Goody, Joan Thirsk and E.P. Thompson, eds., Family and inheritance. Rural society in Western Europe, 1200-180o (Cambridge, 1976) 192-327.

158 Frederik Dhondt, 'From Contract to Treaty: The Legal Transformation of the Spanish Succession (1659-1713)', Journal of the History of International Law 13 (2011) 347-375.

159 Linda and Marsha Frey, A Question of Empire: Leopold I and the War of Spanish Succession, 1701-1705 (Boulder, 1983) 13. See also Jean Bérenger, 'Une tentative de rapprochement entre la France et l' Empereur: le traité de partage secret de la succession d' Espagne du 19janvier 1668', Revue d'Histoire diplomatique 79 (1965) 291-314, 294-295. 
If we examine succession arrangements, we get a similar picture. Austrian Habsburgs do figure in the succession scenarios that were elaborated in the testaments of the kings of Spain. But only Austrians who were children of Spanish princesses ranked high in the order of succession. For instance, Maximilian II's children were directly behind Philip II's own children in the line of succession due to his marriage to Philip's sister. But Austrians who were not-for instance, the Styrian branch, which had no female Spanish ancestor-were omitted entirely. ${ }^{160}$ However, when the branch descended from Philip II's sister became extinct, their privileged place in the succession as secondary heirs was taken by the House of Savoy, descended from Philip II's daughter Catalina $(1567-1597)$, rather than by any other Austrian branch. This indicates that interHabsburg solidarity could never trump the genealogically based rights of other houses who were more closely related to the Spanish Habsburgs.

Genealogical proximity between the Austrians and the Spanish played a part in the participation of Austrian Habsburgs in the Spanish patrimony. Of Maximilian's six sons, four were educated in Spain, and three of these were considered as possible husbands for Philip's daughters, and three were provided for by the Spanish, through offices or inheritance. ${ }^{161}$ Furthermore, one son who was not educated in Spain served briefly as a rebel governor in the Low Countries. However, such close co-operation was not a result only of good family relations. In fact, Philip II intended to raise his nephews because he was suspicious of Maximilian's religious stance. In this sense, a court education under their uncle's eye was in fact an indication of mistrust between the branches. Furthermore, when we review the treatment of such nephews, it is clear that their value derived from the fact that they were a sister's children, rather than from their membership in the overarching Habsburg dynasty. There is hardly any difference in the way Savoyard and Austrian nephews were treated at the Spanish court. Three Savoyard nephews were also educated at the Spanish court (again because their Spanish uncle did not trust their father very much), one of whom - as well as two further sons - served the Spanish monarchy in some capacity. ${ }^{162}$ Children of Spanish women who were not Austrians were thus favoured equally with court educations and livelihoods, and could represent the Spanish king as a governor just as well as agnatic Habsburgs.

\footnotetext{
160 Geevers, 'Miracles of Spain', 296.

161 Liesbeth Geevers, 'Dynasty and State Building in the Spanish Habsburg Monarchy: The Career of Emanuele Filiberto of Savoy (1588-1624)', Journal of Early Modern History 20 (2016) 267-292, 271.

162 Geevers, 'Dynasty and State building', passim. Emanuele Filiberto served as prior of Castile and León in the Order of St. Juan, admiral of the Habsburg Mediterranean fleet and viceroy
} 
Overall, the Austrian branch of the family was closely related to the Spanish branch, and war between the two never broke out. However, the memory of common descent from Philip the Fair-the father of Charles $v$ and Ferdinand I-does not appear to have been a great unifying force. This force was provided by the frequent marriages of Spanish princesses into the Austrian branch. Such standard genealogical connections were not unique to the Austrians, as the example of the Savoyards shows. Inter-Habsburg solidarity probably prevented wars from breaking out - it did not in the case of Savoy or Francebut in terms of marriages or the succession, the ties between the two branches were regulated according to the generally accepted norms of dynasticismnothing more. The Spanish Succession crisis-precipitated by the childless death of Charles II (1660-1700) in 1700 but anticipated long before that dateended Habsburg rule in Spain and in fact illustrates the 'kinship-over-dynasty' principle remarkably well. Charles II, aware that he was about to die without direct heirs, was adamant that his entire inheritance should pass to one heir without being divided. The heir he chose was not, however, a Habsburg, but a Bourbon. Not only were the Bourbons not part of the Habsburg 'Gesamthaus', but neither had any of them ever served in any capacity within the Habsburg Monarchy (unlike scions of the houses of Farnese, Savoy, and Medici). However, at the moment when Charles identified his heir, none of this mattered, but only the kinship ties connecting the king and his heir: Charles's eldest sister had married Louis XIV of France. Skipping over direct heirs to the French throne (Charles's nephew, the Dauphin, and grandnephew), Charles chose his sister's second grandson - aptly named Philippe.

On the whole, we conclude that marriages, successions, and participation of relatives in rule would be influenced more by kinship and blood ties rather than by the concept of the Domus Austriae-with closely related Savoyards or Bourbons preceding slightly 'adrift' Austrian Habsburgs. The power of the dynastic concept as social glue among its members was thus particularly strong when kinship ties were close.

\section{Conclusion}

In order to overcome the main problem of comparatists-how to make sure one had equal knowledge of the different cases one is comparing — this chapter

of Sicily; his brother Cardinal Maurizio was protector of Spain at the Vatican, while his other brother Tommaso Francesco served as general of the Netherlandish army during the Thirty Years' War. 
was written by two authors who extensively discussed the possible questions to be asked of our two fields of expertise, the Jochids of the Golden Horde and the Spanish Habsburgs. Instead of formulating questions deriving from our own specific historiographies, we chose to devise a definition of dynastic rule based on elements of our two cases. Keeping in mind the three elements of dynastic rule that we identified - the passing on of assets, i.e. succession; the constructing of a dynastic concept; and the social realities of joint dynastic rule-we returned to our own source material.

\section{Successions}

Perhaps succession is where one would expect to find the greatest differences between the nomads' bloody 'free-for-all' and European strict and orderly primogeniture. Such ideas are clearly exaggerated stereotypes, because in both of our cases the importance of 'the right heir', who was acceptable to elites and thus could uniquely foster cohesion in the empire or monarchy, was paramount.

Combining our analyses of the Jochids and the Habsburgs, we can note several differences in the way these lineages passed on their assets to future generations, and how these practices came about. Habsburg successions were influenced above all by local dynastic traditions, some of which were translated to the level of the wide-ranging monarchy of the sixteenth and seventeenth centuries. Particularly Castile's male-preference primogeniture became a guiding principal for the succession, while Austria's tradition of partition became obsolete in the seventeenth century. The Jochids, on the other hand, showed less a process of blending influences, since the Mongol tradition did not compete with others, but we notice nevertheless a process of 'emancipation' from the great khans. The election procedure of the great khan-election by assembled begs and other members of the nomadic elite - was replicated at the local level in the Golden Horde, a translation in the opposite direction, from the overarching dynasty to its local offshoots. Contrary to what is commonly asserted, the Mongols favoured primogeniture. The old rules of post-mortem inheritance practiced by East-Asian herders were not the ones the Chinggisids had decided to follow - they might have been inspired by previous imperial practices, especially by the Khitans (Liao) who had also established the rank of the sons in accordance with their mother's and primogeniture. As we have seen through various examples including Khans Batu, Berke, and Möngke-Temür, the Jochids always preferred primogeniture, even if they did not see it as mandatory. ${ }^{163}$

163 See Holmgren, who believed that the Mongols followed traditional steppe inheritance 
In both empires the number of heirs and claimants was instrumental in shaping the 'atmosphere' of the succession. Plural heirs led to conflicts everywhere, and uncles and nephews might be at odds in both empires. The Jochid succession was limited to only two branches until the fourteenth century; a number not unlike the number of Habsburg collateral lines. In any case, across the board adult males were considered to be entitled to part of the dynastic assets. If they did not receive their due, they might threaten the ruler. As a general rule, adult males posed a problem that needed to be solved. Interestingly the Jochids did not concentrate power and assets on the heir-designate and never deprived uncles, brothers, and nephews of political and military powera significant departure from other systems including the Han, the Ottomans, and the Mughals after Akbar. ${ }^{164}$

In terms of succession law, both empires showed flexibility although Habsburg laws (where they existed) where slightly clearer in designating a specific individual than the Chinggisid yasa - an evolving body of laws-which identified many claimants. In both empires, codified law played a limited role in the end. In the Mongol case, as recent scholarship shows, the yasa was less important than the procedural laws implemented during the quriltai, great consultative assemblies. Questions concerning imperial marriages and inheritance patterns, divorces, and remarriages were discussed during these collective meetings where elite women, too, had a say. ${ }^{165}$

The Golden Horde did not codify any succession laws, but their stable practices show they had firm rules. Yet under dramatic circumstances, like the brutal death of a ruler or the lack of direct heirs, practices might diverge, as in the case of Khan Berke, who did not have a solid claim to rule because of the relatively low status of his mother. He managed to gain and consolidate power, but after his death, the rules established under Chinggis Khan and his first successors - preferential primogeniture and precedence of the candidates according to their mother's rank - prevailed again.

The Spanish Habsburg Monarchy as a whole did not have a codified succession law either. And even where it existed — that is, in the separate clusters

procedure in which 'the chief heir was in most cases the youngest son of the first wife', but noted that in the Mongol empire 'the youngest son did not necessarily inherit the position of supreme ruler'. She attributed this discrepancy to the democratic force of the quriltai ('Observations on Marriage and Inheritance Practices in Early Mongol and Yuan Society' 146-151).

164 Munis Faruqui, The Princes of the Mughal Empire, 1504-1719 (Cambridge, 2012).

165 Hodous, 'The Quriltai as a Legal Institution in the Mongol Empire', 87-102; Broadbridge, 'Marriage, Family and Politics: The Ilkhanid-Oirat Connection', 121-135. 
that formed the Monarchy — practices might still deviate from the law. In the end, the various 'illegitimate' successions in medieval Castile show that traditional ideas about ideal rulers (adult males with Reconquista credentials) were stronger than codified laws that identified women or children. This experience still resonated in the seventeenth century, when Philip IV displayed sincere anxiety about his succession, even though he had a sturdy daughter, who was perfectly eligible and acceptable. Philip's desire for a son and the phasing out of partitions of the patrimony do show that male-preference primogeniture and the exclusion of women and younger brothers had taken firm root in the seventeenth century. But we might argue that the Spanish Habsburg Monarchy conformed to this typically 'European' succession pattern rather late. Rather than being some engrained and essentially European tradition, primogeniture was slowly introduced to the Spanish Habsburg Monarchy as a whole - not by law, but by testamentary provisions.

Common views about primogeniture as a typically European and sedentary feature versus multigeniture supposedly dominant in the nomadic societies need to be revised. Primogeniture imposed by the ruling group created stability and had the huge advantage of neutralizing a number of conflicts (as nature or God had decided). But primogeniture could work only when a ruler had sons. This raises an important question: how flexible could an empire be when the circumstances prevented the elites from following the rules? How far could they go in changing or adapting the laws? The Jochids temporally allowed changes, but they also developed rituals to make these changes acceptable to their world order and to reassure the spirits of the ancestors and the living. Among these rituals, one of the most important was that involving losing contenders, who 'gave up the throne' as a token gesture. ${ }^{166}$ But there was one rule about which the Jochids remained inflexible: the Chinggisid patrilineality of the throne contenders. To belong to the golden lineage was always an absolute precondition for being elected Khan. Thus, the Jochids would include in their pool of pretenders the offshoot of a secondary lineage or the sons of a concubine over the sons of the Chinggisid princesses.

\section{Dynastic Concepts}

Looking back at both the Jochid and Habsburg dynastic concepts, it appears that genealogy and descent were more important for the Jochids than they were in the Habsburg case. Certainly in the sixteenth and seventeenth cen-

166 See, for example, the scene of the quriltai before Ögödeis' enthronement described in: Rashid al-Din Compendium of Chronicles, vol. 2, 312. 
turies, all Habsburgs descended from Maximilian and his only son Philip the Fair, which simplified matters greatly. Although almost all sixteenth-century genealogies mention all the different medieval branches of the Habsburgs, some seventeenth-century texts start only with Philip the Fair (last common ancestor of the two early-modern branches). ${ }^{167}$ The Jochids, however, had to deal with eleven lineages, some of which rose to prominence only after many generations of obscurity and therefore reinvented their genealogies to bolster their prestige. Perhaps as a result of the genealogical simplicity of the Habsburgs, their dynastic concepts were much more focused on the 'mission' of the dynasty - to conquer all the world in order to defend the Catholic faith. The Jochids mixed the Chinggisid ideology of world-dominion that dated back to the times of Great Khan Ögödei with elements coming from the Islamic Sunni tradition. As early as the second half of the thirteenth century, Khan Berke's letters to the Mamluk Sultan Baybars show that new elaborations were taking place in the Muslim circles of the Golden Horde in which Islamization would strengthen the khan's legitimacy. But the religion of the Jochid ruler remained a 'plus' or a 'minus'; it would not be a sine qua non before the second half of the fourteenth century when the Ilkhans and the Mongol Yuan collapsedmarking the real end of the Mongol Empire.

However, in both cases we note how malleable dynastic concepts were and the extent to which they depended on the contemporary context in which they were formed. Clearly, historians must always consider dynastic concepts in their specific contexts instead of mistaking them for historical facts. This means dynasties were constantly re-inventing themselves and re-connecting themselves to their subjects. Dynastic concepts were therefore inherently unstable and changeable. A central core usually served as the foundation of the dynastic myth (for instance, the mythical ancestor, the claims to world power), but the individuals who were connected to these central elements could change. This was, for instance, the case when the hierarchy among the Jochid branches changed or when the Habsburg House split into two branches. Dynastic concepts were the ultimate example of the flexibility of ideals and traditions, which were remodelled to paper over dynastic discontinuities or to find support for the ruling house among newly acquired territories and their elites. Their importance for fostering cohesion within empires cannot, therefore, be overstated.

167 See, for example, Philip Kilian, Genealogia serenissimae domus Austriacae: a Philippo Primo, Rege Hispaniarum, altero Austriacae magnitudinis fundatore, ad Augustissimos Caesares Leopoldum et Margaretham deducta (Graz, 1666). 


\section{Social Realities}

When we turn from concepts and theories to practices, we can see that in both the Jochid and Habsburg cases, dynastic rule was not a matter for single monarchs: a wider group of people was involved, as contenders, electors, or helpers. Our dynastic case studies clearly show the 'composite character' of kingship, or rulership, as a 'mixed bag' involving others beyond the nominal ruler-even if he or she was a forceful and competent character. In the Jochid case, these additional powerbrokers are actually incorporated into genealogies of the ruling clan as 'sons-in-law'. The Jochids practiced preferential marriage with the Qonggirat, but there was not 'simultaneous exchange' between them. The Jochid princes maintained their marital strategies open and pragmatic. Polygyny, as we have seen, had almost no impact on internal succession, as the Mongols used it for political relations and diplomacy. For outsiders, the impassable barrier to entering the golden lineage was compensated for by the possibility of joining the ever-growing group of the 'sons-in-law' — a group that could never reach the supreme office but could rule nevertheless. The Jochid princesses were married to important vassals, like the Armenian and Russian princes, and to begs or heads of the local nomadic elites. They sometimes married influential neighbours, such as the Ilkhanids and the Timurids, but they never married complete foreigners. ${ }^{168}$ In any case, Chinggisid matrilineality could never lead to khanship.

We also come across some 'son-in-law'-families in the earlier Habsburgs genealogies (most notably the houses of Bavaria and Lorraine in Morigi's genealogy), but in the strongly patrilineal seventeenth-century genealogies we lose sight of them. Spanish princesses had rights of inheritance, and so did their offspring. But since Habsburg in-laws were always foreign princes (who were occasionally at war with their fathers- and brothers-in-law) their role in the Habsburg power structure differed fundamentally from the role of Jochid inlaws. Normally, only junior members of in-law-lineages - the king's nephews and nieces - were allowed to participate in Habsburg rule. Nevertheless, both cases demonstrate how important collateral kinsmen really were and thus also the connections established between different lineages through marriages.

As we have seen, the Jochid system fell in between monogamy and polygyny. Indeed even in the cases when the khans converted to Islam - which already

168 The marriage of the khan's niece Tulunbay Khatun with the Mamluk sultan al-Malik alNasir Muhammad b. Qalawun, in 1320, was considered exceptional by the Jochids themselves. See Marie Favereau, 'The Golden Horde and the Mamluks', in Rafael Khakimov, Vadim Trepavlov, and Marie Favereau, eds., The Golden Horde in World History (Kazan, 2017) 338-339. 
reduced the number of legal wives to four-only the sons from chief wives were eligible for the succession. This meant that the number of Jochid heirs was less than the total number of sons, and that the contrast with monogamous Europe was not as huge as might be expected.

When discussing dynastic rule, historians - whether they were fourteenthcentury Castilian chroniclers, Rashid al-Din, Ibn Khaldun, or modern-day scholars, have often tended to present us with a sequence of rulers. ${ }^{169}$ Although rulers actually strove to present a picture of flawless and inevitable successions from ruler to ruler, in practice, such images could not be further from the truth. Genealogies - certainly those of older lineages about whom we have little other source material-tend to construct history rather than reflect it, by smoothing over ambiguous kinship connections and contentious successions. Furthermore, European genealogies tend to obscure the role of collateral kinsmen-descended from the lineage's women-even though they were very much part of the dynastic project. Jochid genealogies actually do include such 'sons-in-law', but historians have rarely taken them into account when analysing dynastic narratives. Genealogies are a wonderful source for reconstructing dynastic narratives and dissecting strategies to create cohesion between rulers and elites, but they tell us next to nothing about how dynastic rule actually worked in practice. Co-operation of relatives was in fact instrumental in maintaining dynastic rule.

Even though numerous differences exist between the Jochids and the Habsburgs, some conclusions can be drawn from this comparative research. First of all, we must draw attention to the role demography played in dynastic successions. Traditions, codified laws etc. guided successions in principle, but in reality the number of available heirs was much more important for determining outcomes. Second, rulers and their ideologues sketched certain images of their lineage-its descent, its branches etc.—but these images were quite changeable and are therefore to be considered only in their immediate context. They are indications of change and discontinuity rather than reflections of order-although this is exactly the impression they strive to convey. Third, image and practice could be miles apart. Dynasties were often represented in a

169 Robert Folger, Generaciones y semblanzas. Memory and Genealogy in Medieval Iberian Historiography (Tübingen, 2003) 12-14 sketches the development of medieval Iberian historiography from mere kings' lists to a collection of profiles of succeeding monarchs to chronicles based on chapters that concern their succeeding reigns; for a modern-day equivalent, see for instance J.H. Shennan, The Bourbons. The History of a Dynasty (London, 2008) which contains the following chapters: 1. Beginnings 2. Henry IV 3. Louis XIII 4. Louis XIV 5. Louis XV 6. Louis XVI 7. Aftermath. 
very patrilineal way, but dynastic rule was a collective effort and everywhere we can notice the role of in-law lineages. Historiography that focuses on individual rulers rather misses the point. Kingship and dynasty are not just concepts, but also social practices involving far more people than conceptual texts about kingship and dynasty would lead us to believe.

Where does this leave those historians who wish to study dynastic rule? How can we re-think this concept? It is clear that when analysing a 'dynasty' we must realize that any 'dynasty' existed both as an idea (a dynastic concept as elaborated in genealogies and funerary architecture) and as a set of social practices, such as successions, elections, and participation in rule. Both these aspects of 'dynasty' were quite changeable over time, but one constant is that dynastic rule never consisted solely of a ruler's solitary actions, but rather was a group effort. In that sense, deconstructing the notion of dynasty and giving up on the traditional list of rulers is a way for historians to re-think the chronology of empires and to reflect on the diversity of their political regimes. 